\title{
Mitochondrial cytochrome $b$ : evolution and structure of the protein
}

\author{
Mauro Deglı Espostı a, Simon De Vries ${ }^{\text {b }}$, Massimo Crimı a , Anna Ghellı a , \\ Tomaso Patarnello ${ }^{\mathrm{c}}$ and Axel Meyer ${ }^{\mathrm{d}}$ \\ ${ }^{a}$ Department of Biology, University of Bologna, Bologna (Italy), ${ }^{b}$ Department of Microbiology and Enzymology, Delft Unwersity \\ of Technology, Delft (The Netherlands), ${ }^{c}$ Department of Biology, University of Padua, Padua (Italy) and d Department of Ecology \\ and Evolution, SUNY Stony Brook, Stony Brook, NY (USA)
}

(Received 18 November 1992)

Key words Cytochrome $b$, Ubıquinone, Respıration inhıbıtıon, Amıno acıd sequence, Mitochondrıal DNA sequence, DNA, Molecular evolution

\section{Contents}

$\begin{array}{ll}\text { Summary } & 244\end{array}$

I Introduction $\quad 244$

II Nomenclature of cytochrome $b$

A The $b$-hemes 244

B The transmembrane helices $\quad 245$

C The two quinone reacting centers in cytochrome $b \quad 247$

III Cytochrome $b$ sequences $\quad 247$

A Source of sequences avallable

B Alignment of cytochrome $b$ sequences

C Discrepancies between DNA sequence and deduced protein sequence 250

IV Natural variation in the structure of cytochrome $b \quad 251$

A Conserved residues 251

B Limitations of sequence analysis and mutagenesis $\quad 254$

C The most and least conserved regions in cytochrome $b$

D Cytochrome $b$ and evolution 255

$\mathrm{V}$ Structural deduction of cytochrome $b$ from sequence analysis $\quad 255$

A Hydrophathy profiles

B Periodicity in the transmembrane helices

VI Structure versus function in cytochrome $b$

A The paradigm of the photosynthetic reaction centers 259

B Cytochrome $b$ residues involved in binding of center I inhibitors 261

C Cytochrome $b$ residues involved in binding of center o inhibitors 261

D Natural resistance as a source of new structure-function relationships $\quad 264$

E Other information relevant for structure versus function 265

$\begin{array}{ll}\text { VII Conclusions } & 267\end{array}$

$\begin{array}{ll}\text { Acknowledgments } & 267\end{array}$

$\begin{array}{ll}\text { References } & 268\end{array}$

Correspondence to M Deglı Espostı, Department of Bıology, Institute of Botany, University of Bologna, Via Irnerı 42, 40126 Bologna, Italy 


\section{Summary}

Cytochrome $b$ is the central redox catalytic subunit of the quinol cytochrome $c$ or plastocyanin oxıdoreductases It is involved in the binding of the quinone substrate and it is responsible for the transmembrane electron transfer by which redox energy is converted into a protonmotive force Cytochrome $b$ also contains the sites to which various inhibitors and quinone antagonists bind and, consequently, inhibit the oxidoreductase

Ten partial primary sequences of cytochrome $b$ are presented here and they are compared with sequence data from over 800 species for a detalled analysis of the natural variation in the protein This sequence information has been used to predict some aspects of the structure of the protein, in particular the folding of the transmembrane helices and the location of the quinone- and heme-binding pockets

We have observed that inhibitor sensitivity varies greatly among species The comparison of inhibition titrations in combination with the analysis of the primary structures has enabled us to identify amıno acid residues in cytochrome $b$ that may be involved in the binding of the inhibitors and, by extrapolation, quinone / quinol

The information on the quinone-binding sites obtained in this way is expected to be both complementary and supplementary to that which will be obtained in the future by mutagenesis and X-ray crystallography

\section{Introduction}

Cytochrome $b$ is the central catalytic subunit of ubiquinol cytochrome $c$ reductase (or $b c_{1}$ complex, EC 11022 ), an enzyme that is present in the respiratory chain of mitochondria [1-6], and in the respiratory chain or cyclic photo-redox chain of many bacteria $[3,7-9]$, it is functionally homologous to the plastoquinol acceptor reductase (or bf complex) of chloroplasts that is involved in both cyclic and non-cyclic light-driven electron transfer [3,10-12] With the exception of protozoans lackıng mitochondria (e $\mathrm{g}$, Trychomonas), all eukaryotic organisms require this general class of redox enzyme, and consequently cytochrome $b$, for energy conservation $[3,9,12]$

Cytochrome $b$ is the transmembrane protein involved in the vectorial oxidation of ubiquinol or plastoquinol and in the electrogenic portion of the catalytic pathway [3,5-16] The Q-cycle mechanısm, originally proposed by $\mathrm{P}$ Mitchell [13], is now widely accepted to be a good description of the redox reactions of the $b c_{1}$ complex $[5,7-9,14,15]$ and it predicts that cytochrome $b$ forms a ubiquinone-reacting center at each side of the membrane Present research on cytochrome $b$ is fo- cused upon how its structure is related to function [5-12]

Our knowledge of mitochondral cytochrome $b$ is expanding very rapıdly, in particular through the analysis of protein sequences predicted from the DNA sequences [5,6,9-12] The importance of aquirıng a vast number of protein sequences is that it enables us to observe just how the proten has evolved while maintaining its function New sequences of cytochrome $b$ are presented here to further document the natural variation of the protein For uncovering additional structure-function relationships, we report a screening of the inhibitor responses of the $b c_{1}$ complex from several different species Since $b c_{1}$ inhibitors bind directly to native cytochrome $b[5,6,9,17-19]$, significant changes in their affinity may arise from variations in the primary structure of the proteın [6,19] A systematic analysis of the sequences avalable and the integration of this analysis with a survey of the properties of inhibitor resistant mutants is presented In this way, we provide a framework for proposing and testing correlations between inhibitor responses and natural variations in the sequence of cytochrome $b$ Some conclusions have been drawn regarding the possible folding of the protein and the connections of its transmembrane helices In view of the flood of sequence information provided recently, comments on the relation between sequence variation in cytochrome $b$ and evolution are also presented in this work

\section{Nomenclature of cytochrome $b$}

Before discussing the data, it is necessary to clarify some issues of nomenclature that concern cytochrome $b$

\section{II-A The b-hemes}

It is well established that cytochrome $b$ contains two distinct hemes with different spectroscopic and redox properties $[2,3,7,8,18,20]$ Unfortunately, various overlapping designations of such hemes have accumulated in the literature Designation according to the maximum of the reduced alpha band (the recommended nomenclature by IUB) is questionable, since the maximum of the $b-562$ heme (in beef heart mitochondria $[20,21])$ varies between 558 and $563 \mathrm{~nm}$ in other species $[3,9,21]$ It is particulary inappropriate for the chloroplast cytochrome $b_{6}$, in which the electronic absorption spectra of two hemes are not easily distinguishable $[3,10]$ Among the properties that are suggested for distinguishing the hemes in diheme cytochromes (cf IUB nomenclature for redox proteıns, G Palmer and J Redık (1992) Eur J Blochem 200, 599-611), we believe that the relative difference in the midpoint redox potential is sufficiently general to be applicable 
for the cytochrome $b$ in all quinol acceptor reductases $[3,7,8,18,21]$ Hence, we shall refer here to $b-562$ as the high potential heme, identified as $b_{\mathrm{H}}$, and to $b-566$ (558) as the low potential heme, identified as $b_{\mathrm{L}}$

\section{II-B The transmembrane helices}

Durıng the past $10-12$ years, as the primary sequences of numerous mitochondrial cytochrome $b$ have

\section{TABLE I}

Species whose cytochrome b is sequenced a

Species (common name) and [reference]

\section{Metazoans}

\section{Mammals and marsupials}

Complete sequences

Homo sapiens (man) [164], Bos taurus (beef) [165], Capra hircus (goat), Ouıs artes (sheep), Antllocapra americana (pronghorn), Giraffa camelopardalis (giraffe), Dama dama (fallow deer), Odocolleus hemionus (black-tailed deer), Tragulus napu (Malay chervotaın), Camelus dromedartus (dromedary camel), Sus scrofa (domestıc pıg), Tayassu tajacu (collared peccary), Equus grevyı (zebra), Diceros bicornis (black rhıno), Loxodonta africana (African elephant), Stenella longirostris (dolphın1), Stenelea attenuata (dolphın2) [32], Mus musculus (mouse) [166], Rattus rattus (rat1) [167], Rattus norvegicus (rat2) [168], Oryncholatus cunculus (rabbit) (F Mignotte, unpublished cf [169]), Balaenoptera physalus (fin whale) [170], Phoca vitulina (harbor seal) [171]

Partial sequences

Equus asinus (donkey), Equus caballus (horse), Oryncholatus cunculus (rabbit *), Felus catus domestıcus (domestic cat) thıs work, 2 Hylobate monkeys (J C Garza and Woodruff, D S, unpublished, cf L02766), Akodon aerosus and other 11 akodontine rodents [86], 4 kangaroo rats and Thomomys townsendl [29], Cephalorhyncus commersonu (small dolphın) [172], Canis cants (dog) and other 4 canıds [173], Canis aureus (golden jackal) and other 9 canids (A Meyer \& R Wayne, unpublished), Ursus maritımus (polar bear), Ursus arctos (brown bear), Ursus amencanus (black bear) [87], Thylacinus (marsupıal wolf) and other 6 marsupıals [85], mandrill, drıll, giraffe ( $\mathrm{R} \mathrm{H} \mathrm{Crozıer,} \mathrm{unpublıshed),} \mathrm{elk} \mathrm{and} 5$ Odocolleus deers (S M Carr and G A Hughes, unpublished, cf M9484), Ornithorhynchus (platypus), Tachiglossus, Zaglossus and ca 10 marsupıals (M Waskman, unpublıshed), 15 African bovids and reındeer (P Arctander, unpublished), sheep and European muflon [174], Thylacinus cynocephalus, 14 dasyurotd marsupials and bandicoot [252], blue whale [253], 2 squirrels (P J Wettsteın, unpublished, M97277-79)

\section{Birds}

Complete and aimost complete sequences

Gallus gallus (chicken) [63], Coturnix coturnix (quail) [197], Colaptes rupicoea (andean flıcker), Scytalopus magellanicus (andean tapaculo), Asthenes dorbigny (canastero), Ampelion stresemanni (cotınga), Putta sordida (pitta), Pomatostomus temporalis (babbler), Pomatostomus istdon (rufous babbler), Amblyornis macgregortae (bowerbırd), Eptmachus albertisu (sıcklebill), Ptiloprora plumbea (honeyeater), Gymmorhina tibicen (magpie), Catharus guttatus (hermit thrush), Parus inornatus (plain titmouse) [33], 17 Phylloscopus species (warblers), Cettia fortipes (Cetti's warbler), Regulus satrapa (gold crest), Sylvia melanocephalus (blackcap) [91], 9 deep-node birds, 7 pıpıts (P Arctander, unpublıshed), Meleagris galtopaco (turkey) and other 7 gallınaceous birds [255]

Partial sequences

Emberyza shoeniculus (reed buntıng) this work, 3 babblers [29,62], Corcorax melanorhamphos (crow) [29], ca 10 birds of paradise and warblers (J Cracraft, S V Edwards, unpublished), 7 Lantartus species (shrikes) [175], 6 cowbirds, 25 blackbırds, Sphyrapıcus vartus, Aulacorhynchus derbianes, Captto niger (S M Lanyon, unpublished, cf [176]), 11 bowerbirds (R H Crozıer, unpublıshed), ca 70 passerıtorms suboscines (P Arctander, unpublished), 2 blue tits and great tit [177], 12 parrots and rock dove [246]

Reptlles

Partial sequences

Uta sp (lizard) this work, Lepidophyma smithu (Lepı lizard) and other 5 xantusıd lizards, Ameiva auberl (tend lızard) [60], ca 10 Lacerta lizards (C Moritz, unpublished), ca 10 Anolls lizards (C Schneider, unpublished)

Amphıbıans

Complete sequences

Xenopus laevts (African toad) [55]

Partial sequences

5 Ambystoma sp (axolotl) and Plethodon yonahlossee [61], ca 10 Ensatına salamanders (T Jackman, unpublıshed), 23 toads (A Graybıal, unpublished), Rana catesbeiana (bullfrog) (Y Yoneyama, unpublished, D00198)

Flshes

Complete sequences

Gadhus morhua (atlantic cod) (C Johansen, unpublished cf [178]), Actpenser transmontanus (white sturgeon) [179], Cyprinus carpio (carp) (F L Huang, unpublished, X61010), Carcharhınus plumbeus (shark1), Carcharodon carcharias (white shark), Sphyrna tıburo (bonnet-head shark) and other 9 sharks [180], Lythrurus roseipinnis (T R Schmidt and J R Gold, unpublished, X66456), Crossostoma lacustre (Taiwan loach) [249], Thunnus thynnus (mediterranean tuna), Sarda sarda (sard), Sgomber sgombrus (mackerel), Boops boops (bogue) and Trachurus trachurus (horse mackerel) (P Cantatore and $M$ Robertı, unpublıshed) 
TABLE I (contınued)

\begin{abstract}
Partial sequences
Astronotus ocellatus (cichlid), Tilapıa mossambica (tılapıa), Hemichromis bımaculatus (cıchlid), Salmo trutta marmorata (trout) this work, Dicentrarchus labrax (bass) (P Cantatore, M Crımı and T Patarnello, unpublıshed, cf [181]), 4 European trouts [182], Sparus auratus (sea bream), Mugil cefalus (grey mullet) and other 4 mugilides (T Patarnello, unpublished), Lycodicthys dearborni, Austrolycichtys brachycefalum (eel pouts) (L Bargellonı and T Patarnello, unpublished), Lepidosiren paradoxa (lungfish1), Protopterus sp (lungfish2), Latımeria chalumnae (coelacanth) [31], Salmo trutta (trout2), Promoxis nigromaculatus (crappie), Gomphosis varus (bird wrasse), Ceophagus steindachner (cichlid), Polipterus (bichir), Megalops atlanticus (tarpon), Atractosteus spatula (alligator gar), Lepisosteus oculatus (spotted gar), Amia calva (bowfin), Pantodon buchholzı (butterflyfish), Scaphirhynchus platorynchus (sturgeon) [64], Julidochromis regani and other 6 Cichlasoma sp (cichlids) [29,90], Astatoreochromis alluaud, Buccochromis atritaentatus, Pseudotropheops tropheops [30] and ca 150 other cichlids, 4 cyprinodonts, ca 60 poecilıds, 8 goodeids 8 characins, 9 stıcklebacks, Gambusia sp (A Meyer, unpublished cf [88,89]), 32 scombrold fishes (B Block, unpublıshed), ca 10 pomacentrids (B Birmingham, unpublished), Angulla rostrata (eel) [90], 8 salmonids [183], Salmo salar (salmon) and brown trout [184], 4 Thunnus sp [185], swordfısh, saılfısh, blue marlın [186], 3 Baıkalıan sculpıns [187], 3 prıckly sharks (G Bernardı and D A Powers, unpublıshed M91183-5)
\end{abstract}

Echinoderms

Complete sequences

Strongylocentrotus purpuratus (sea urchın1) [45], Paracentrotus lvvdus (sea urchın2) [46,188], Arbacla lixula (sea urchın3) (F DeGiorgı unpublıshed), Pisaster ochraceus (sea star) [189], Asterina pectınfera (starfish) [190]

Arthropods

Complete sequences

Drosophila yakuba (fly1) [191], Drosophila melanogaster (fly2) [248], Anopheles quadrimaculatus (mosquito) [192], Artemia franciscana (shrimp1) (R Marco and R Garesse, unpublished), Daphnia (shrimp2) [193], lobster (D Stanton, unpublished), Apts mellifera (honeybee) [194], Tetraponera rufoniger (ant) [254]

Partıal sequences

Euphasia superba (krill) this work, Pandalus borealis (Greenland shrımp) (H Lund, unpublished), 2 Artemia shrimps (J R Valverde unpublished, X67264), 9 ants, 4 bees, 3 wasps (R H Crozler, unpublished)

Helminths

Complete sequences

Ascarts suum (round worm), Caenorhabditts elegans (free-living worm) [54]

Partial sequences

Parascaris equorum (M Deglı Espostı, unpublıshed), Fasciola hepatica (Irver fluke), Melenogyne jovanica (F DeGiorgi, unpublished, cf [195])

Other invertebrates

Complete and partial sequences

Mytlus eduls (blue mussel) [196], Metrdium senle (D R Wolstenholme, unpublished cf [195]), ca 10 clams (E Boulding unpublıshed), Lombricus terrestris (earthworm) (M Deglı Espostı, unpublished), 2 Antarctıc clams (T Patarnello, unpubhshed)

\title{
Non metazoans ${ }^{b}$
}

Yeasts and fungl

Saccharomyces cerevisiae [37], Saccharomyces douglasu [41], Schizosaccharomyces pombe [57], Kluyveromyces lactis [198], Candida glabrata (G D Clark-Walker, unpublıshed), Aspergillus nidulans [199], Neurospora crassa [200], Podospora anserna [201], Strobilurus tenacellus, 2 Mycaema sp (G Von Jagow, unpublished), Pneumocystis cannil (partial [202]), Allomyces macrogynus, Spizellomyces puctuatus, Rhizopus stolonifer, Rhizophlyctts rosea (B F Lang, unpublished ${ }^{c}$ )

\section{Protozoans}

Trypanosoma brucel (flagellate) [48,49], Lesshmania tarentolae (flagellate) [49,203], Crithidia fasciculata (flagellate) [49,204], Leishmania infantum (flagellate) (partıal, L Gradonı and M Deglı Espostı, unpublished), Plasmodium gallinaceum (apıcomplexan) [205], Plasmodium yoelu (apicomplexan) [47], Plasmodium falciparum (apicomplexan) [163], Theilena annulata (apıcomplexan) [160], Toxoplasma gondı (apıcomplexan, partial [162]), Paramecum aurelia (cyliate) [56], Tetrahymena pyriformis (cyliate), Acanthamoeba castellanil (ameboid, M W Gray, unpublished ${ }^{\mathrm{c}}$ ), Phytophthora infestans (B F Lang, unpublıshed ${ }^{\mathrm{c}}$ ), Physarum polycephalum (slıme mould) (D Miller, unpublished cf [50])

\section{Algae (mitochondra)}

Chlamydomonas reinhardtu [124,206], Chlamydomonas smuthu [206], Chlamydomonas moewusu [207], Chlorella [208], Ochromonas dantca, Prototheca wickerhamil, Porphyra sp, Plocamiocolax pulvinata, Gractlanopsis lemanetformis (G Burger and B F Lang, unpublished ${ }^{\mathfrak{c}}$ )

Plants (mitochondra)

Tritcum aestuum (wheat) [51,209], Zea mays (maize) [210], Oryza satwa (rice) [211], Oenothera villaricae (berteriana) (evening primrose) [52,53], Solanum tuberosus (potato) [212], Vicia faba (broad bean) [213], Helianthus annuus (sunflower) (R Galleranı, unpublished and R H Koehler unpublished), Arabidopsis thaliana (A Brennicke, unpublished [53]), Marchantia polymorpha (liverwort) [214] 
TABLE I (contınued)

Purple bacteria

Rhodospirllum rubrum [43], Rhodopseudomonas vindls [2151, Bradyrhizobium japonicum [216], Rhodobacter capsulatus [217], Rhodobacter capsulatus strain Ga [96], Rhodobacter sphaeroides [44], Paracoccus denitrificans [218], Thiosphaera pantotropa (T DeBoer, unpublıshed)

Other bacteria

Chlorobum limicola (G Hauska, unpublished), Heliobacillus chlorus (V Vermaas, unpublished), Bacillus PS3 ( $b_{6}$-1ıke) [82], Sulfolobus actdocaldarius (SoxC subunit binding heme $a$ in a quinol oxidase) [70]

Cytochrome $b_{6}$ of the cytochrome $b_{6} f$ complex

Plants and algae (chloroplasts)

Spinacia oleracea (spinach) [23,219], Nicottana tabacum (tobacco) [220], Zea mays (maize) [221], Ptsum sattum (pea) [222], Trittcum aesttuum (wheat) [223], Hordeum vulgarts (barley) [224], Oryza satwa (rıce) [225,251], Marchantıa polymorpha (liverwort) [226], Chlorella protothecotdes (green alga) [227], Chlamydomonas reinhardtu (green alga) [228]

Cyanophyta

Nostoc PCC7906 [229], Agmenellum quadruplicatum [12]

Subunit IV of cytochrome $b_{6} f$ complex

Plants and algae (chloroplasts)

Spinacia oleracea (spinach) [23,219], Nicottana tabacum (tobacco) [220], Zea mays (maize) [221], Pisum sattum (pea) [230], Trtticum aestivum (wheat) [223], Hordeum vulgaris (barley) [224], Oryza sattva (rice) [251], Cuscuta reflexa [250], Marchantia polymorpha (liverwort) [226], Chlorella protothecoldes (green alga) [227], Chlamydomonas reinhardtu (green alga) [2281, Scenedesmus obliquus [231], Chlamydomonas eugametos (green alga) [232]

Cyanophyta

Nostoc PCC7906 [228], Agmenellum quadruplicatum [12], Synechocystss sp PCC6803 [233]

a Partial sequences of cytochrome $b$ have been obtained herein after extraction of mitochondrial DNA (from either mitochondria or frozen tissues) and PCR amplification with the primers and the experimental conditions described previously [29-32,89,90] Our PCR sequence of rabbit $\left(^{*}\right)$, which was obtained in collaboration with Prof $\mathbf{P}$ Cantatore (University of Bari), is identical to the sequence of the cloned gene obtained by F Mignotte (personal communication) Sequences that are under way or unpublished are referred to the principal scientists who are working on them In some cases of unpublished sequences the EMBL-Genbank accession number is reported Our DNA sequences of donkey, reed buntıng and krill are deposited in the EMBL bank Note that for some species, e g, axolotl [61], babbler [62], cod [178] and cichlids $[30,88]$, sequences from several individuals are reported The list is updated to february 1993 and includes a survey of the releases of Genbank and EMBL databanks that was performed by Dr M Attımonell, University of Bar1, Italy

b All complete sequences except when otherwise stated

c Species being sequenced withın the Canadian Organelle Genome Sequencing Project (G Burger and B F Lang, personal communication, cf [247])

been determined, a number of overlapping designatıons of the predicted structural elements of the protein have accumulated This is particularly the case for the putative transmembrane helices, which were inıtially designated with roman numerals [22,23] Later, either letters $[8,18,24,25]$ or arabic numbers $[9,19,26]$ have been used concomitantly with the roman numerals [10-12,21,27] Herem, we shall conform to the nomenclature proposed by Crofts $[24,28]$ in which the likely transmembrane helices are defined by capital letters and the extramembrane loops by the lower case letters of the helices connected by them

\section{II-C The two quinone reacting centers in cytochrome $b$}

In addition to the two heme groups, the $b c_{1}$ complex contains two functionally-distinct sites at which ubiquinone interacts with cytochrome $b$ in the reductase enzyme The original designation of such sites as centers $\mathbf{i}$ (proton input) and o (proton output) proposed within the Q-cycle mechanism [13-15] is probably the most widely used, and we shall conform to it Other common nomenclatures of the quinone centers are $Q_{1}, Q_{n}, Q_{c}, Q_{r}$ or $Q_{n}$ for center $i$ and $Q_{o} Q_{\text {out }}, Q_{z}$ or $Q_{p}$ for center o [6-10,17-19,24-28]

\section{Cytochrome $b$ sequences}

\section{III-A Source of sequences avallable}

A series of scientific circumstances has rendered cytochrome $b$ the most sequenced membrane protein today The voluminous literature on the function of the $b c_{1}$ complex, the isolation of the complex from differ- 


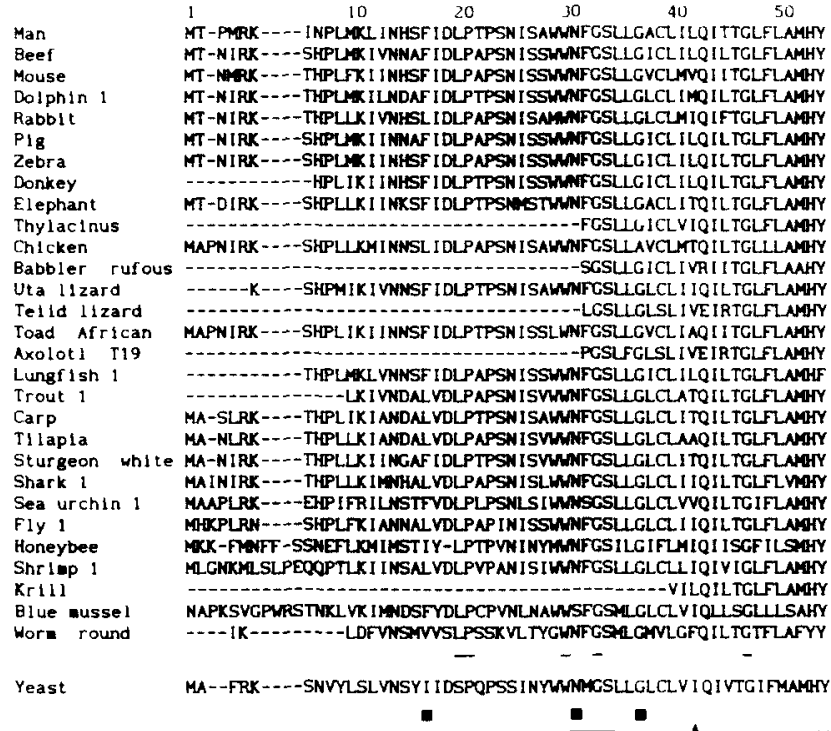

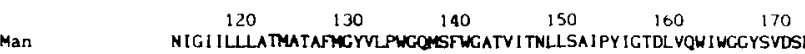
Beef NIGVILLLTMATAFACYVLPWCOMSFWGATVI TNLLLSA] PYIG TDL VOW IWGGYSVOSP

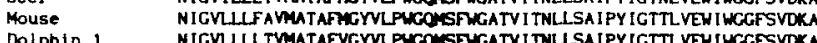

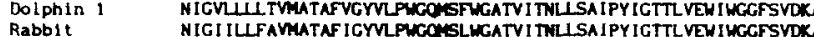
Rabbit NIGIILLFA MATAFICYMLUCOSLLWGATVI TNLL SAIPYIGTTLVEVIWGCFSVDEA

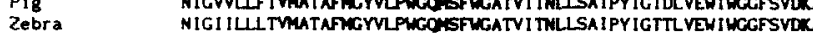

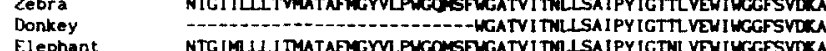

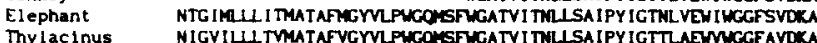

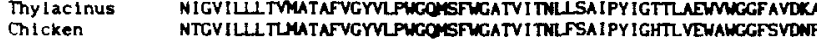

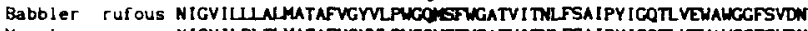
Magpie NIGVILPLTUMATAFVGYVLWCONSFUGATVITMLFSA IPY ICOTL VEWAWGGFSVOWP

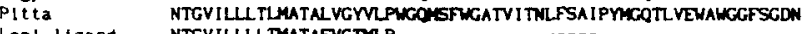
Lepl Lizard NTGVILLLLTMATAFYGTMP

Toad African NIGVILLFL VMATAFVGYLPWCOESFUGATVITML LSAVPY IGNVLVOWSLGGFSVDA

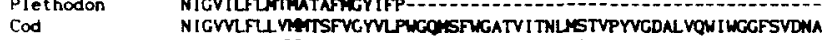

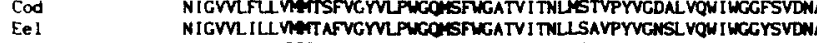

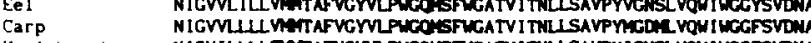

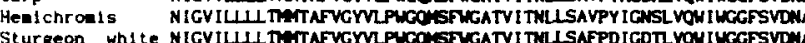

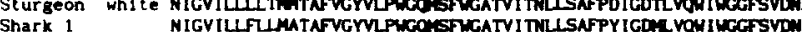

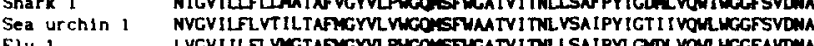

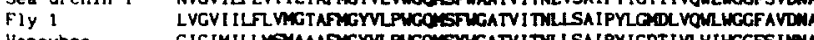

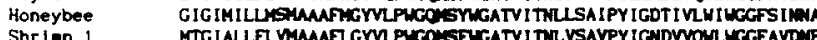

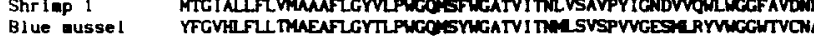

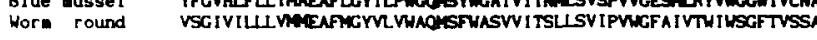
Yeast NVGVIIFILTIATAFLCYCCWCONSHMGATVI TNLFSAIPFVGNDIVSHLUCCFSVSWP $C$

Man

Mouse

Dolphin 1

Came!

Pig

Zebra

Elephant

Chlcken

Babbler rufous

Magple

Toad African

Bulifrog

Cod

Carp

Sturgeon white

Shark 1 urchin 1

Sea star

Fly 1

Mosquil to

Shriap 1

reast

$\begin{array}{llllll}240 & 250 & 260 & 270 & 280 & 290\end{array}$ LFLSLMLTL SPDLLDPDWYTLNPLIPPHIKPEWTLFAYT ILASVPNICCVLA

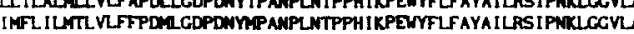

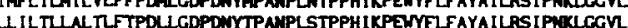
LILIWM TLFAPDLCDPDMYTPAMPLSTPAHIKPEWYFL FAYA ILRS I PUKLLCGVA LULALL ILVLFSPOLLCDPOWYTPANPLTPPHIEPEWYFLAYAILPSIPIELCGVLA

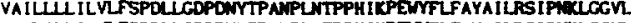

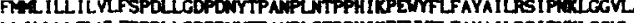

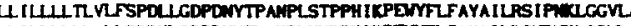

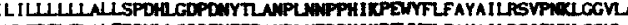

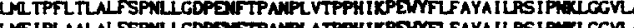

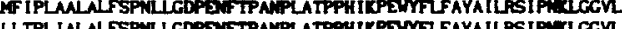

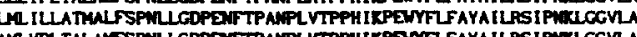

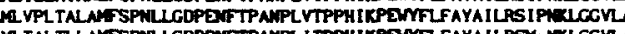

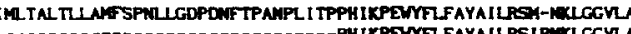

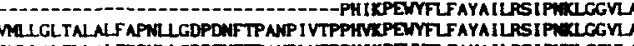

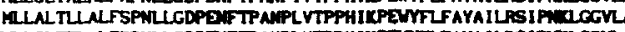

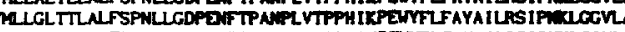

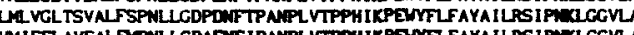

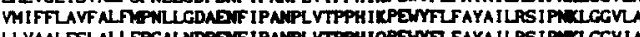

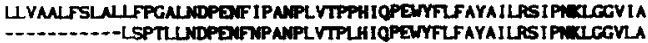

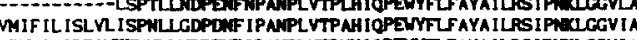
作

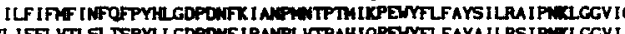
VLIFFLVTLSL ISPYLLCDPOWF IPANPLVTPAHIOPEWFLFAYAILPS IPACLCGV IA LRA ILN.FVFYSPTLGKPOWY I PGNPL VTPAS IVPEMYU LFYAILAS IPDKLL LVIT
Man

Beef

Dolphin

Rabbit

Pig

Donkey

Elephant

Thylacinus

Babbler ruf
Uta lizard

Teild lizard

Plethodon

Lungf Ish

Trout :

Carp

Sturgeon white

Sea urchin

Fly 1

Shrlap 1
Krlll

Blue mussel
Horn round

Yeast

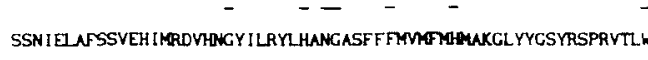

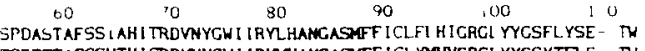
TSDTTIAFSSVTHICRDWNYGU1 1 RYMHANGASAFF ICL MOVGRCLYYGSYTFLE- TW TSDTMTAFSSVTHICRDVWYGWL IRYMAANGASAFF ICLFL HVCAGL YYGSYTTME-DW

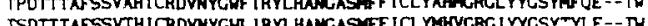
TSDTT SSTH TSDTTAFSSTHICRDYUYCWI IPY

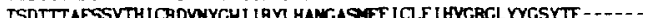
TPDTMAFSSNSHICRDVWYGWI IROLHSWGAS IFFL CLYTH IGRN I YYCSY YSE--TV

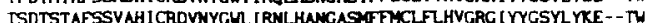

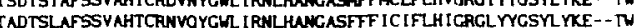

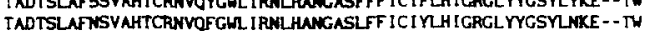
TADISSAFSSVAHIHRDVQYGML IRN I HAMGASAFFICIY TADTSLAFSSVANICRDVOYGWL LPTHANGASAFF ICIYLHIGRGI YYGSYFHXE- - AN TADTSNAFSSVAHICFDWWYCLL IRNLHANGLSFFF ICI YLHI IGRGL YYCSFL YKE--TW

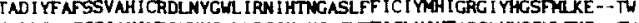

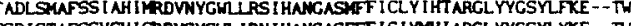
TSDISTAFSSVCHICROVSYCWL. IRN IHANGASFFFIC I YHAI IARGE YYCSYLYKE- - TN TSDISTAFSSVTHICRDVWYCIL IRWVHANGASFFF ICI MHI I ARGL YYCSYL YKE- $T$ W

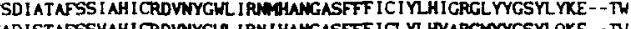

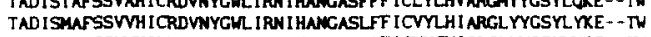

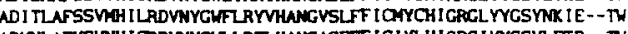
CPNID IAPUS ITN ICRDWNYGLL IRTLHANGASFFF ICI YLHLCRCI WCSYLFTP - - T

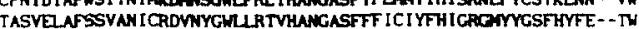

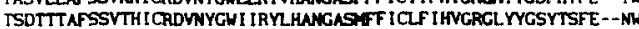

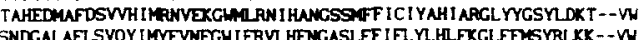
SSNI ELAFSSVEH IMRDVHACY ILRYLHANGASFFFMVATMMAKGLYYCSYRSPRVTLW
Man

Beef

Dolphin 1

Camel

Pig

Donkey

Thylacinus

Chicken

Blackcap

Babbler rufous

Magple

Toad African

Cod

Earp

Astronotus

Sturgeon

Shark I
Sea urchln 1
Fly 1

Honeybee

Shrim ?

Yeast

Man

Beef

Dolphin !

Fin what

Rabbit

PIg

Zebra

Olackcap

Magple

Canastero Toad Africat
Bullifrog

Cod

Carp
Astronotus

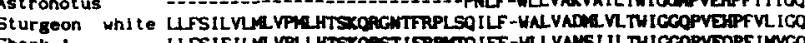

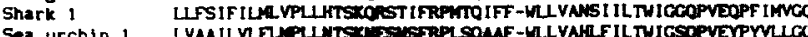

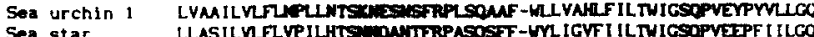

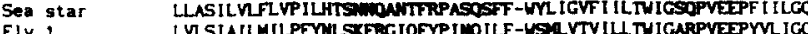
Fiy 1 into

Mosquito

Shrint 1

Wort round VLSIALUILPFYLSWFAC IOFYP INO ILF-WSA VTVILLTWIGAPPVEPYYLIGC

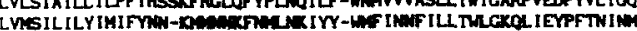
LVSSILILVSLPFTTXFKFHGLEFYSVAOPLF-USWVSVFUIITHIGAPPVEDPVFRCO

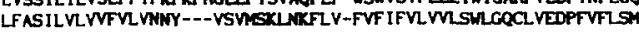
MFMILVLVLPFTDRSYVRCNTFKVLSKFFF-F IFVFNFVULCOIGACTVEVPYVLACO

Yeast TL TRFF AFHF ILPF I IMA I ANVHLL FUHETCSNMPTG ISSDVDK IPFHPYYT IKD ILGAL TLTRFFAFHF ILPF I I TALAVHLL FLHETGSWNPTG IPSADM IPFYPYYT IKD ILCGL

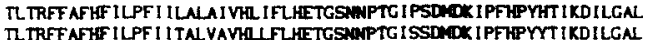

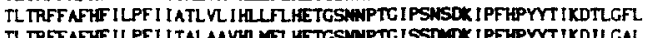
TLTRFF AFHF ILPFI I TALAVHL MFULTESSMPTC ISSDOXK IPFHPYYT IKDILGAL

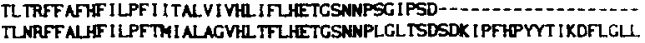
TLTFFF AFHF ILPS IVTALATVHLL LLHETCSNAPSG INPDSDK IPFHPY-..........

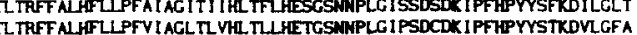

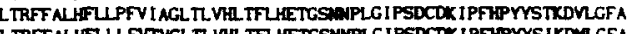

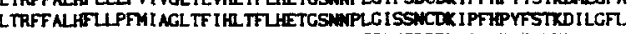

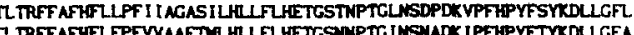

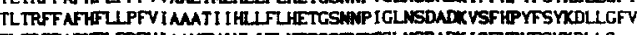

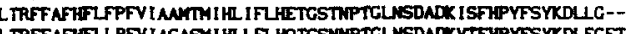

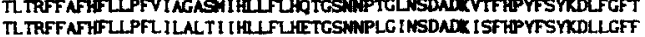

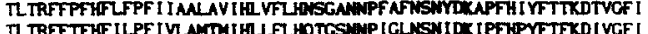

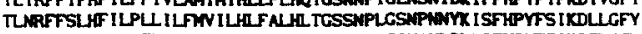

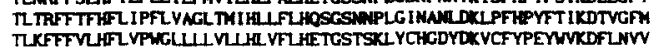
TI IQRFFALHM VPF I I MAMV I MHLMALH I HGSSNPLG I TCNLOR I PMASYF IFKDLVTVF 0

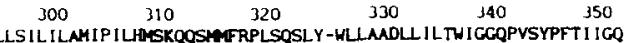
LAFSILILAL IPU HTSKORSATFPL SOCLF - WAL VADLL TLT IG IGOPVEYPYITIGQ

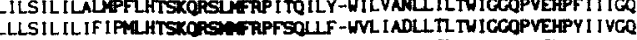

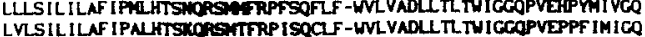

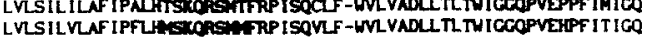
VASIL LILS IL ILALIPTLHTSROASEAFRPLSOCVF-WLL VADLL TL TVI CCOPVEYPVMI ICO L

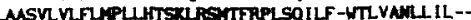

MSV VLFLIPLHASELASTTPRPLSOILF - WALVANLLVLTVVS

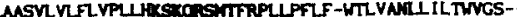

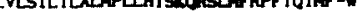

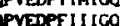

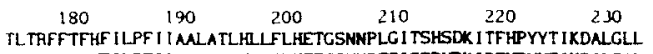




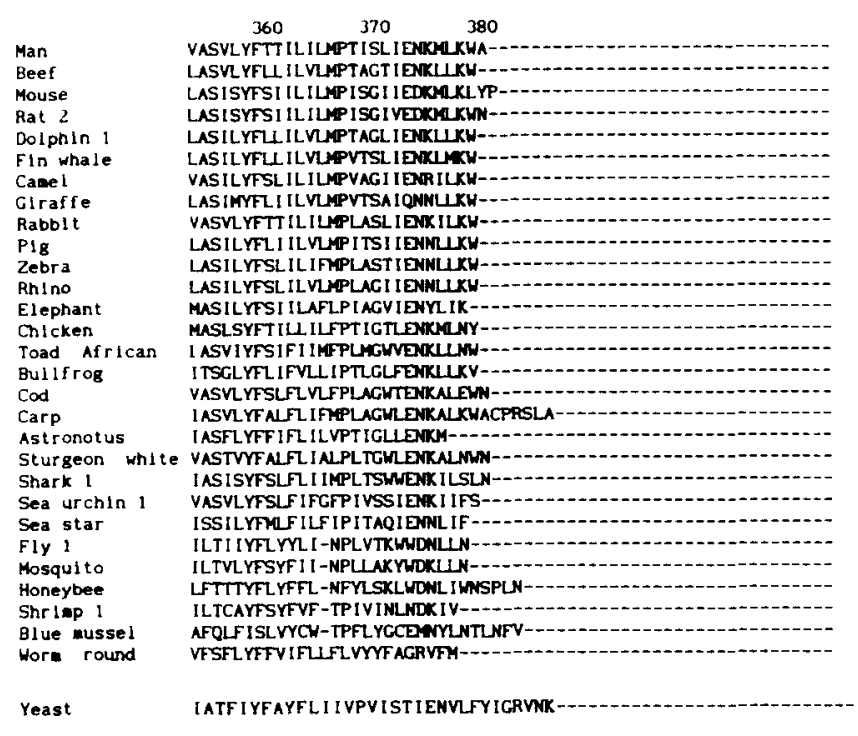

YHב
Fig 1 Alignment of partial and complete sequences of mitochondrial cytochrome $b$ proteins Amıno acid residues are alıgned and numbered according to the protein from yeast ( $S$ cerevisiae $[37,41]$ ) The sequences are shown in decreasing order of sequence conservation among the thirty species per alıgnment block and each block has a slightly different set of species (see Table $\mathbf{I}$ for the scientific name of the species and the references) The partial sequence of axolotl refers to individual 19 of Ambystoma tigrinum Ontario [61] The uncertain $\mathrm{N}$-termınus of the blue mussel protein [196] has been cut by ten residues The 56 underlined residues are considered to be conserved in all other sequences of metazoan anımals that have been analyzed thus far, including human variants $[244,245]$ Although the reported DNA sequences would show substitutions of some of these conserved residues, such substitutions consistently derived from single base changes and they were ignored on the basis of our criterion for removing plausible errors (see text and also $[32,39,46]$ ) This criterion was applied in the following cases in addition to those discussed in Table II R79 $\rightarrow$ A in one salamander [61], R99 $\rightarrow Q$ in one salamander [61] and $R 99 \rightarrow P, W$ in two marsupials [252], N115 $\rightarrow \mathrm{T}$ in one Bajkal fish [187], L122 $\rightarrow \mathrm{P}$ in magpie [33], S140 $\rightarrow \mathrm{A}$ in one marsupial [252], T145 $\rightarrow \mathrm{S}$ in two birds [91] and T145 $\rightarrow \mathrm{I}$ in one marsupial [252], T148 $\rightarrow \mathrm{M}$ in one marsupial [252], G168 $\rightarrow \mathrm{S}$ in one marsupial [252], L193 $\rightarrow \mathrm{R}$ in Thylacinus [252], F275 $\rightarrow \mathrm{L}$ in one shark [180] The substitutions in Ref [61,91] are indeed sequence errors (B Hedges and A Richman, personal communication) The lines at the bottom of the alignment detıne the predicted transmembrane helices (Identified by capital letters, cf [24]) The symbol a marks the positions where mutations induce resistance towards center 1 inhibitors (Table III) and the symbol $\bigcirc$ identifies the positions where mutations induce resistance towards center 0 inhibitors (Table

IV) Only mutations changing a single residue are shown

complete sequences - including ours - from metazoan species (Fig 1), and the other containing only complete sequences of phylogenetically diverse species (Fig 2)

\section{III-B Alignment of cytochrome $b$ sequences}

The crucial step in the analysis of any protein with many variants is to align the sequences in a way that maxımızes the structural equivalence of homologous regions $[6,11,34,35]$ This seems to be relatively easy for the sequences of cytochrome $b$ from anımals, which generally show more than $50 \%$ identity $[11,22,32]$, but it becomes much more difficult when other sequences are considered, particularly those from protozoans $[6,11,27]$ These sequences often have less than $25 \%$ Identity with those of other taxa and present some unusual features that are difficult to interpret in the absence of a three-dımensional structure (cf the globins [34]) To align the cytochrome $b$ sequences, we have selected first the complete sequences which are less than $86 \%$ identical to each other [36] This criterion was initially chosen to include the sequences from both Leishmania and Trypanosoma and to reduce the phylogenetically uneven representation of the species (Table I) The sequence of the yeast $S$ cerevistae [37] proten

forms (Table I) We present the alignment of the sequences in two parts one containing partial and 
has been taken as a reference for consistency with previous studies $[5,9,21,23,25-27,36]$

Subsequently, the program CLUSTAL [38] has been applied to the selected sequences This method is based upon the progressive clustering of related sequences and introduces many gaps to align the least homologous regions [38] For cytochrome $b$ sequences, the poorly homologous $\mathrm{N}$ and $\mathrm{C}$-termını were thus alıgned with a great number of gaps However, application of the CLUSTAL procedure removed some mismatches that were present in previous manual alıgnments $[6,11,12,26]$ In particular, a rational alıgnment of the region 100-114 (yeast numbering) was obtained, with only two single gaps in metazoans vs yeast (Fig 1) and no gap in cytochrome $b_{6}$ at position 100 (F1g 2)

The alignment has been refined further by employing the following approaches First, a subset alıgnment of all the sequences from protozoans to those of yeast and plants has been carefully performed [39] Secondly, consensus sequences [34] have been computed for the major groups of phylogenetically-related species $(1 \mathrm{e}$, anımals, yeasts / fungı, plants, protısts, bacteria and chloroplast $b_{6}$ ) and they have been aligned to each other Thirdly, the average hydropathy profile, the common sequence motifs, and the positions of the intron-exon junctions were concomitantly utllized as a guide for locatıng the gaps and insertions to yield minimal interruptions of the transmembrane helices $[34,39,40]$ Finally, all the avalable sequences were compared simultaneously to minımize insertions and deletıons in the $\mathrm{N}$ - and $\mathrm{C}$-terminal regıons according to the principles outlined in Refs 34, 35, 40

Prelıminary forms of the above alıgnment have been discussed previously $[27,36,39]$, the present alignment (Fig 2) includes sequences that show less than $70 \%$ identity (except for the $b f$ subunits) and belong to the most phylogenetically diverse species For instance, the sequences of just one mammal and one nematode are included to represent animals All the data in Figs 1 and 2 have been carefully checked from the original and from the most recent references (quoted in Table I) in order to remove errors and to update the deduced amino acid sequences (e $\mathrm{g}$, position 69 in yeast is now known to be Met [41] and not Ile as in the first report [37])

\section{III-C Discrepancies between DNA sequence and deduced protein sequence}

The amıno acid sequence of cytochrome $b$ is, in most cases, deduced from the DNA sequence of its gene The DNA sequence has been confirmed by direct sequencing of small peptides in beef [42], man (I M Fearnley and J E Walker (1987) Bıchemistry 26, 8247-8251), potato (F P Braun and UK Schmitz, unpublished) and two bacteria [43,44] It is inevitable that DNA sequencing errors are present in such a large data base for cytochrome $b$ (Table I) Indeed, if we had to rely solely on the DNA sequences reported in the literature, we would come to the disturbing conclusion that none of the four histidines that are necessary to ligate the two hemes in cytochrome $b$ [6-11,18,22,23] would be fully conserved In some cases, it has already been clarified that errors were present in the original reports (P Cantatore, R H Crozier, S B Hedges and A Richman, personal communication and Refs 32, 45-47) Additionally, mitochondrial genes in protozoans [48-50] and higher plants [51-53] undergo RNA-editıng, so that the amıno acid sequence does not correspond entirely to the sequence deduced from the DNA The edited sites have been identified for the cytochrome $b$ of trypanosomes $[48,49]$, a slime mould (D Miller, personal communication, cf [50]) and some plants [51-53], and they consistently lead to more evolutionarily conserved amino acid sequences The corrected sequences were not avallable in previous alıgnments, thereby leading to an incomplete evaluation of the conservation of certain residues such as the aromatic residue at position 94 (Fig 2, cf Refs 6, 11, 21)

Having the above considerations in mind, we have adopted a parsimonious view of the possible variations in the primary sequence of cytochrome $b$ Whenever we encountered some very unusual substitutions in the alıned sequences, we analyzed whether such substitutions could be structurally 'implausible' (e g, Refs 34 , 39) It would be implausible, for example, that only the nematode protein has the hydrophobic Phe at position 178 where all other species have the charged Arg or Lys (Figs 1 and 2) However, the same type of substitution is seen at position 70 in African toad [55], position 79 in Paramecium [56] and position 288 in $S$ pombe [57], thereby indicating the occurrence of $R(K)$ to $F$ substitutions in regions of cytochrome $b$ that are exposed at the positive side of the membrane

Contrary to the above cases, the most frequently occurring odd substitutions of very conserved residues could be pinpointed to a single base change in the DNA codon After consultıng colleagues who reported sequences containing some of such substitutions, we learnt that they were errors in nearly all cases The most efficient criterion for removing these random errors is the following Any single base change leading to the substitution of an extremely conserved residue is ignored when this change is seen only in one of several related species The applications of this criterion are listed in Table II and in the legend of Fig 1 (see also below and [39]) In view of these corrections for plausible errors, the alıgnments in Figs 1 and 2 represent our parsimonious picture of the cytochrome $b$ sequences 
TABLE II

The most highly conserved amino acids in cytochrome $b$

\begin{tabular}{|c|c|}
\hline \multicolumn{2}{|c|}{ Residue ${ }^{a}$ Conservation, notes and references } \\
\hline G33 & complete, heme pocket $[18,36]$ \\
\hline G47 & complete except $E$ in one lizard [60], probably invariant ${ }^{b}$ \\
\hline G75 & $\begin{array}{l}\text { complete except D in Paramecium [56], probably } \\
\text { invariant [39] }\end{array}$ \\
\hline R79 & $\begin{array}{l}\text { incomplete } \mathrm{F} \text { in Paramecum }[56] \text { and } \mathrm{H} \text { in some } \\
\text { animals }[252,254,255]\end{array}$ \\
\hline H82 & complete except $Q$ in flıcker [33], probably invariant ${ }^{b c}$ \\
\hline S87 & $\begin{array}{l}\text { incomplete D in Paramecium [56] and } \mathrm{T} \text { in some ants } \\
\text { [254] }\end{array}$ \\
\hline H96 & complete, hgand of one $b$ heme [65] \\
\hline R99 & probably complete as positively charged $^{b}$ \\
\hline W114 & complete, function unknown \\
\hline G117 & $\begin{array}{l}\text { complete except } A \text { in one salamander [61], probably } \\
\text { invariant }\end{array}$ \\
\hline F129 & incomplete $\mathrm{L}$ in pitta [33] and $\mathrm{V}$ in chloroplast $b_{6}{ }^{\mathrm{d}}$ \\
\hline G131 & complete except $E$ in giraffe [32], probably invariant ${ }^{b} \mathrm{c}$ \\
\hline Y132 & $\begin{array}{l}\text { incomplete } L \text { in Paramecium [56] and } T \text { in one lizard } \\
\text { [60] }\end{array}$ \\
\hline S140 & complete except $\mathrm{G}$ in chloroplast $b_{6}$ \\
\hline W142 & $\begin{array}{l}\text { incomplete I in Paramecium [56] and F in Bacillus PS3 } \\
\text { [82] }^{\mathrm{f}}\end{array}$ \\
\hline T145 & incomplete $\mathrm{V}$ in nematodes [54] and $\mathrm{K}$ in chloroplast $b_{6}$ \\
\hline V146 & incomplete I in Paramecium [56] and chloroplast $b_{6}$ \\
\hline T175 & complete except $\mathrm{M}$ in canastero [33], probably invarıant ${ }^{\mathrm{b}}$ \\
\hline H183 & complete, ligand of one $b$ heme \\
\hline H197 & $\begin{array}{l}\text { complete except D in } P \text { lividus [188], probably } \\
\text { invariant }{ }^{\text {bc }}\end{array}$ \\
\hline $\mathrm{H} 202$ & complete except $\mathrm{R}$ in chloroplast $b_{6}$ \\
\hline D229 & $\begin{array}{l}\text { complete except E in Paramectum [56], probably } \\
\text { invariant b }\end{array}$ \\
\hline I269 & $\begin{array}{l}\text { incomplete V in Paramecium [56] and cod } \\
\text { (C Johansen, unpublished) }\end{array}$ \\
\hline P271 & complete, function unknown \\
\hline E272 & $\begin{array}{l}\text { complete except } \mathrm{H} \text { in Paramecium [56], probably } \\
\text { invariant }\end{array}$ \\
\hline W273 & complete except $C$ in a deer [32], probably invariant ${ }^{b}$ \\
\hline L282 & $\begin{array}{l}\text { complete except } F \text { in one shark [180], probably } \\
\text { Invariant } b, \mathrm{~h}\end{array}$ \\
\hline K288 & incomplete $\mathrm{F}$ in $S$ pombe [57] and $\mathrm{H}$ in Paramecium [56] \\
\hline G291 & complete except $V$ in one alga [231], probably invariant ${ }^{b}$ \\
\hline
\end{tabular}

${ }^{a}$ According to the alignment of Fig 2 extended to all the avalable sequences (Table I) with the exception of SoxC of Sulfolobus - this protein binds heme $a$ and belongs to a quinol oxidase [70] - and of the cytochrome $b$ - like genes found in the nuclear DNA of some species (see Refs 75, 162 and references therein) It should be noted that the residues $\mathrm{G} 33$ and $\mathrm{S} 87$ can be mutated to alanine without altering the activity and assembly of the reductase [18]

${ }^{b}$ After ignoring substitutions of extremely conserved residues that could be due to a single base change of the DNA (see text and Fig 1 legend)

c This histıdine is almost certainly conserved as the ligand of one $b$ heme $[8,65,71]$

${ }^{d}$ Its mutation to L in myxothiazol resıstant mutants [137] does not alter significantly the function of ubiquinol cytochrome $c$ reductase [36]

e Its mutation to S produces a fallure of the protein assembly [151] and can be restored partially by secondary site mutations $[76,152]$ Recent sequencing of the giraffe gene confirms G131 (R H Crozier, personal communication)

\section{Natural variation in the structure of cytochrome $b$}

\section{$I V-A$ Conserved residues}

The comparison of the primary sequences of homologous proteins from distantly related species indicates the amino acids that are phylogenetically conserved In principle, conservation arises from the requirement of specific amıno dcids for functional or structural properties of the protein $[34,35,58]$, as illustrated for cytochrome $c[58,59]$ In eukaryotic cytochromes $c$, as in hemoglobins [34], the phylogenetically invariant residues generally form the heme binding pocket or lie in crucial positions within the three-dimensional structure of the protein $[58,59]$ A similar situation may be extrapolated to occur in cytochrome $b$, for which, at present, sequence comparison is the principal source of information to indicate important residues, since no atomic structure is avallable

In the first comparison of six sequences of mitochondrial cytochrome $b 121$ residues ( $31 \%$ of the total) appeared to be invariant [22] This number decreased to 39 when an additional 12 mitochondrial and bacterial sequences were compared [11] From our comparison of about 800 mitochondrial sequences (Figs 1 and 2), we see only 9 invariant amino acids, and this number is not affected by the comparison with the bacterial sequences An additional 10 residues may be invariant If we ignore unique substitutions that could be due to a single nucleotıde error (see above and Ref 39 ) Only two of the invariant residues are not conserved in chloroplast cytochrome $b_{6}$ (Table II)

Table II lists the invariant residues and those that appear to be conserved except for one or two species so far From the comparison of the animal sequences of cytochrome $b$, several amino acid residues considered previously to be invariant $[6,9,11,18,27,36]$ show substitutions in two unrelated species or arising from two base changes in the codon, hence, they can not be excluded by the consistent application of our criterion of error removal These residues include $\mathrm{Q} 43$ (A or E in reptiles and salamanders $[60,61], \mathrm{R}$ or $\mathrm{K}$ in some birds [33,62] - it is also $M$ in $R$ rubrum [43]), the negatively charged residue at position 71 ( $\mathrm{N}$ in birds $[29,33,62,63]$ and also in $R$ sphaeroldes [44]), F129 (L in one bird [33]), Y132 ( $\mathrm{T}$ in one lizard [60] and $\mathrm{L}$ in

\footnotetext{
${ }^{\mathrm{f}}$ Its mutation to $\mathrm{R}$ induces respiratory deficiency in yeast, but function is restored by revertants having $T$ or $S$ at the same position [153]

g Its mutation to $\mathrm{H}$ or $\mathrm{E}$ induces antımycin resistance in $R$ rubrum and significant functional changes (A Trebst, personal communication)

${ }^{\mathrm{h}}$ Its mutation to $\mathrm{F}$ induces respiratory deficiency in yeast (D Lemesle-Meunıer, unpublished)
} 
Paramecium [56]), T145 ( $V$ in nematodes [54]), the positively charged residue at position 178 ( $\mathrm{F}$ in nematodes [54]), P187 (A in Paramecium [56], L in magpie [33]), T265 ( $\mathrm{N}$ in elephant [32] and $\mathrm{S}$ in nematodes [54]), 1269 (V in Paramectum [56] and cod - C Johansen, unpublished), and P286 (missing in African toad [55])

On the other hand, some reported changes are so unique or drastic, even if they do not occur at very conserved positions, that one may ask whether they are due to sequence errors With the sequences presented here, we have demonstrated that two such cases are likely errors S37 in one trout [64] - other trouts as well as all anımals except chıcken [63] have G37 - and L89 in Jultdochromis [29] - other fishes have F and all anımal sequences have an aromatic residue at this position (Fig 1)

The most important prediction advanced for the structure of cytochrome $b$, that the doublets of histıdınes in helices $B$ and D are the ligands of the heme Irons $[22,23]$, was based on the evolutionary invariance of these residues and this conclusion still holds [65] However, the assignment of the ligands to each heme had to be revised after the withdrawal of the former helix IV from the membrane $[5,6,19,21,24-28,65]$ Some of the previous speculations on the possible roles of other phylogenetically conserved residues are not fully sustained by the more extensive sequence alignments For instance, the binding of the propionyl groups of the hemes has been proposed to involve the positively charged residues at position 79, 99, 178 and 202 $[12,22,23]$ Since R79 is not conserved in Paramecuum [56] and some anımals (Table II), nor R178 in nematodes [54], these four residues are not the only candidates for the heme propionyl interaction Moreover, H202 may be too distant to bind a propionyl group of the $b_{\mathrm{H}}$ heme as deduced from proteln modeling studres (data not shown)

In other hemeproteins the amıno acids which bind the heme propionates are not strictly conserved $[34,35,59]$ Therefore, Y103 might be an alternative hydrogen bond donor to the propionates of the $b_{\mathrm{H}}$ heme, even if this residue is not conserved in some protozoans (Fig 2) The involvement of specific residues in heme propionate binding could be tested by studying the $\mathrm{pH}$ dependence of the redox potential of the $b$ hemes in species or mutants having substitutions of these residues This $\mathrm{pH}$ dependence is influenced by the nature of the amino acids that are hydrogen bonded to the heme propionates of cytochromes ( $\mathrm{ff} \mathrm{Cal,} \mathrm{M}$ and Timkovich, R (1992) FEBS Lett 311, 213-216)

From the spacing of four helical turns between the invariant histidines and spectroscopic information (see Refs 21-23 and references therem), it is estımated that the edge to edge distance between the two hemes in cytochrome $b$ may be around $12 \mathrm{~nm}[6-10,21-23]$
This distance is sufficiently small to allow rates of electron transfer between the two hemes in the mullisecond time range ( $1 \mathrm{e}$, the turnover of the enzyme, cf R A Marcus and N Sutın (1985) Brochim Biophys Acta 811, 265-322), but is also consistent with est1mates of rates of electron transfer in the microsecond time range (cf Refs 7, 8, 14-16) If the latter is true, changes in the rate of electron transfer between the two hemes of roughly a factor of $1000,1 \mathrm{e}$, as long as this rate is not in the millisecond time range, would not be detected experimentally We realize that, in the absence of a 3D structure for cytochrome $b$, compar1son of many primary sequences does not add suff $1^{-}$ ciently strong arguments to discriminate between the two concepts regarding electron transfer in biological systems proposed in Ref 66 and Ref 67 Nevertheless, alignment of the primary sequences does indicate that the interheme distance is probably similar in all cytochrome $b$ proteins, thereby constraining the electron transfer rates between these redox groups More generally, the nature of the transmembrane amıno acids appears to be relatively unimportant, an observation seemingly more compatible with Ref 67

On the other hand, the evolutionary invariance of a few ionizable residues in cytochrome $b$ that lie near the lipid/water interphase of the membrane may reflect a crucial functional or structural role In particular, the negatively charged residue that is conserved at each side of the membrane (D229 at the negative side and E272 at the positive side) could be involved in the protonation equilibria of ubiquinone at either center 1 or o Prelımınary results obtained by site-dırected mutagenesis of these residues in $R$ sphaerotdes appear to confirm their functional importance [8]

Several glycines are invariant or highly conserved in cytochrome $b$ (Fig 2 and Table II) By analogy with $c$ cytochromes [58,59] and other hemeprotens [34,35], the evolutionary invariance of glycines in cytochrome $b$ may be related to sites of severe steric constraint in the structure or to sites involved in the heme packing $[18,36]$ In particular the four invariant glycines in cytochrome $b$ that are separated by 13 amino acids each in helices $A$ and $C$ (Fig 2) are remarkably symmetric to the two doublets of the ligand histidines, which are also separated by 13 residues $[11,22,18,36]$ This observation suggests that these glycines may contribute to the heme pocket [36] Mutation of one of these glycines at position 33 destabilizes the protein and affects the $b$ hemes $[8,18]$, thereby supporting the predicted structural role Furthermore, saturation mutagenesis of the highly conserved G143 residue has established that there are also severe steric requirements in the extramembrane regions of cytochrome $b$ $[68,69]$

The symmetric motif of transmembrane glycines and histidines is characteristic of cytochrome $b$ and is not 


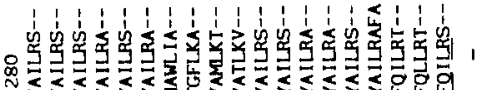

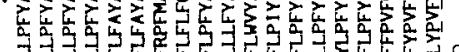

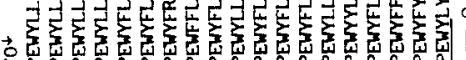
is

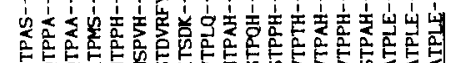

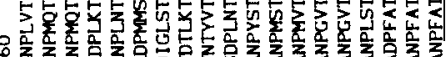

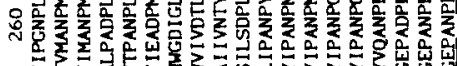

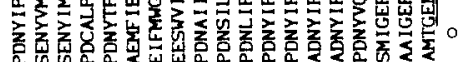

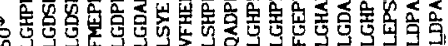

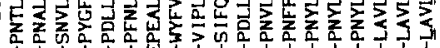

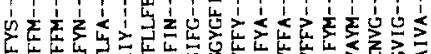

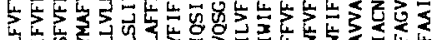

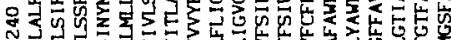

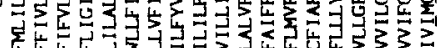

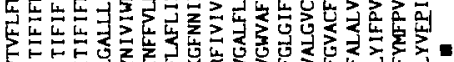
तु

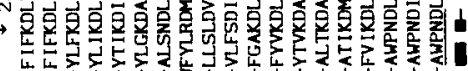

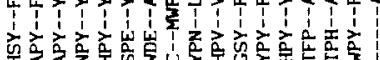

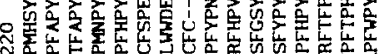

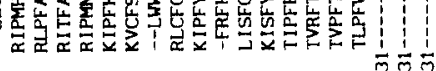

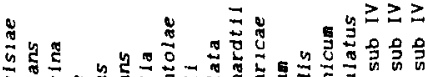

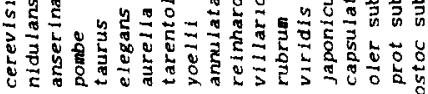
n

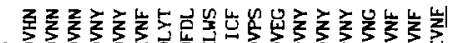

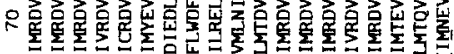

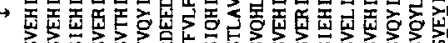

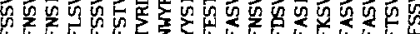

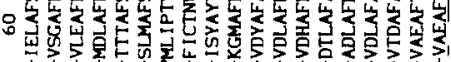

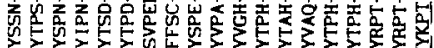

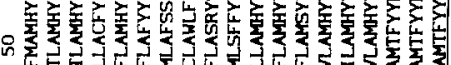

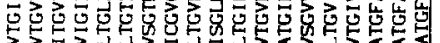

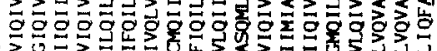

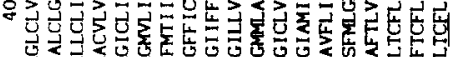

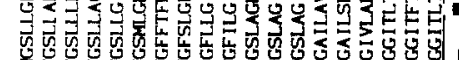

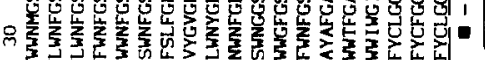

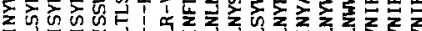

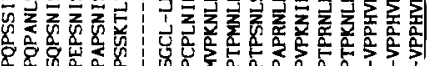

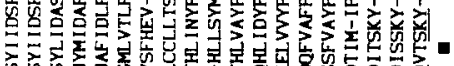

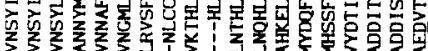

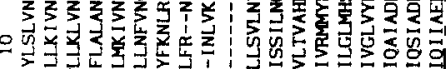

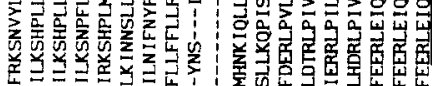

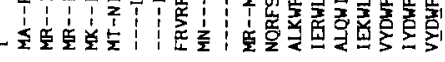
ตับ

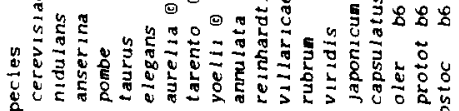

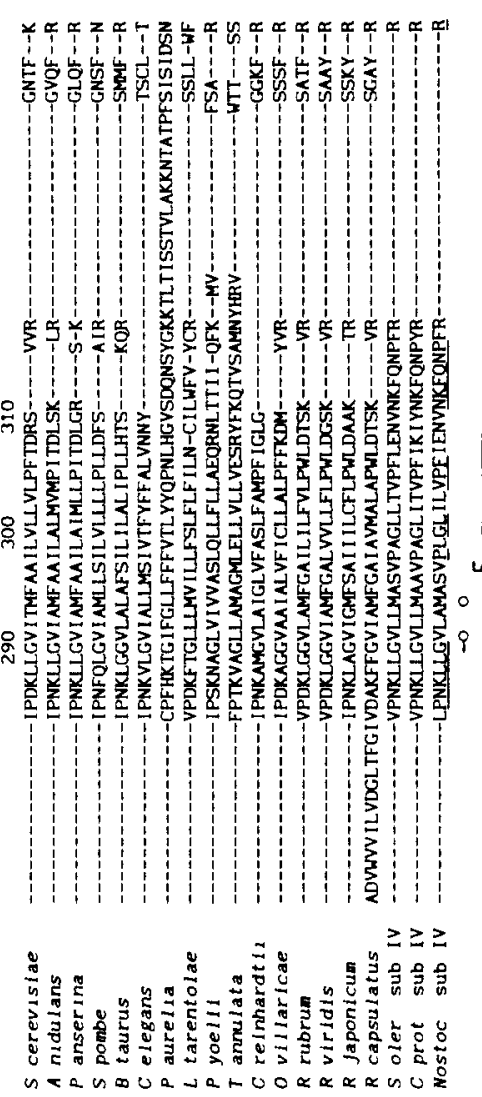

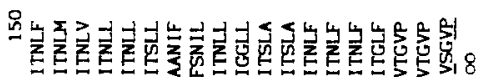

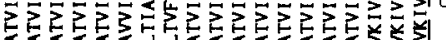

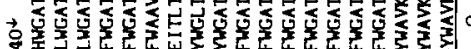

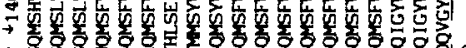

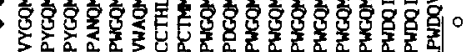

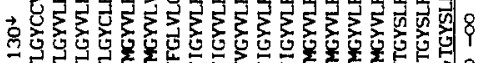

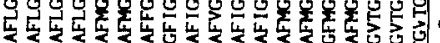

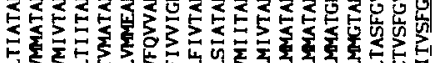

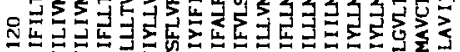

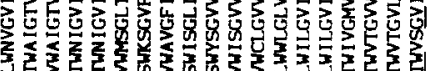
을

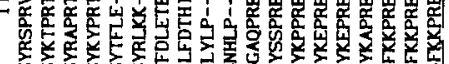

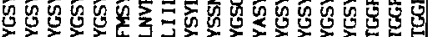

8

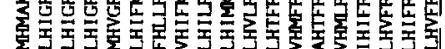

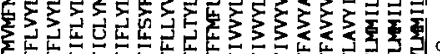

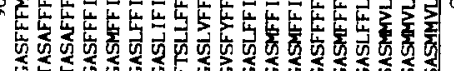

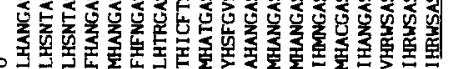
D地

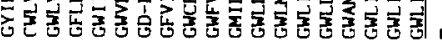

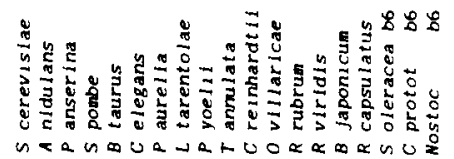

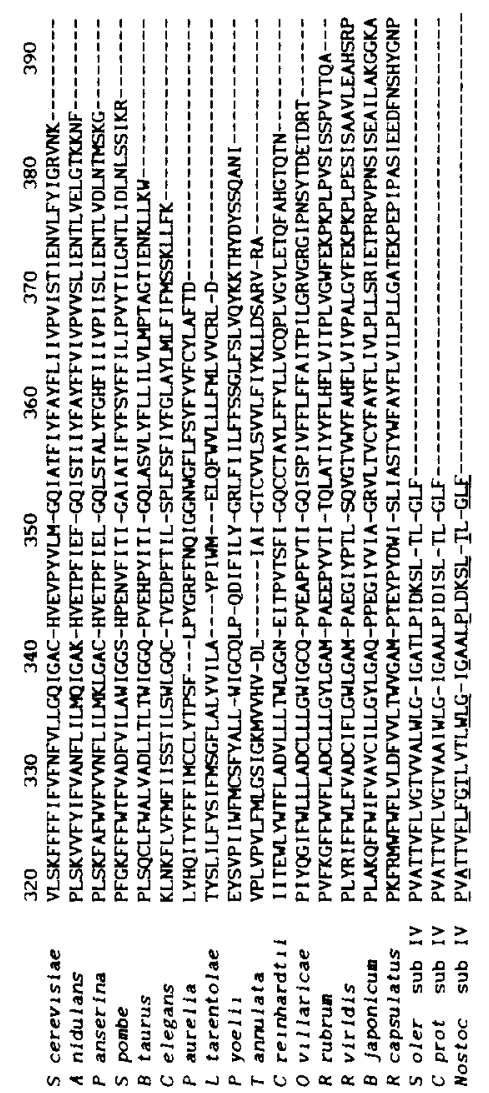

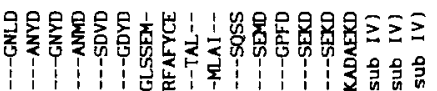

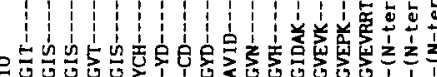

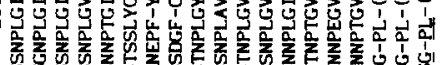

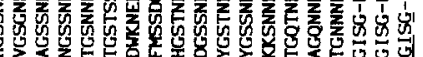

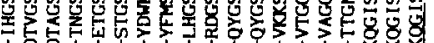

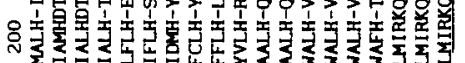

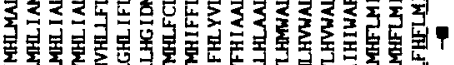

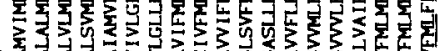
\&

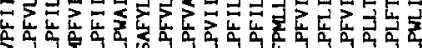

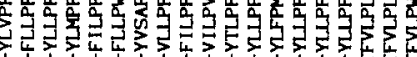

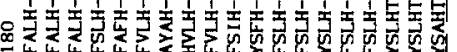

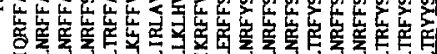

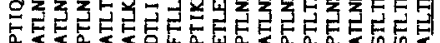

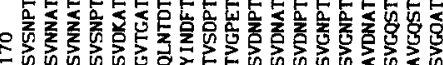

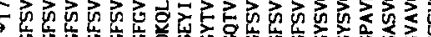

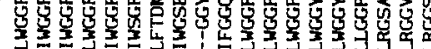

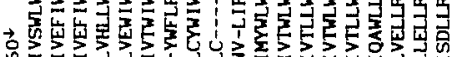

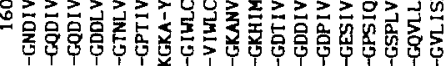

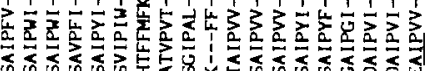

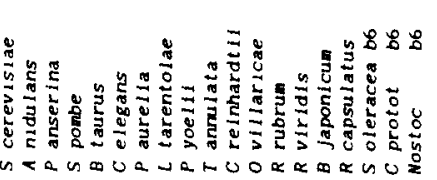

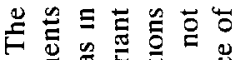

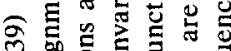

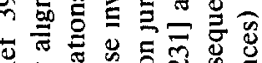

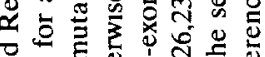

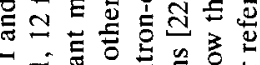

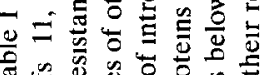

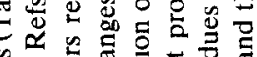
舟语

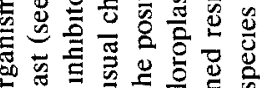
边语

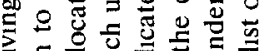

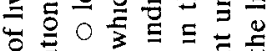

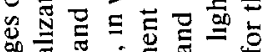

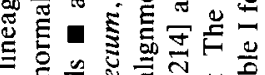
$\div \approx \bar{\sigma}=\frac{0}{\pi}$

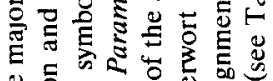

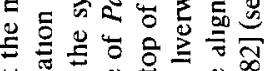

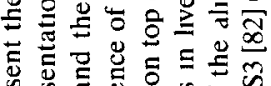

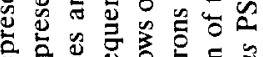

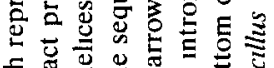

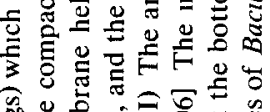

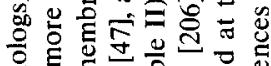

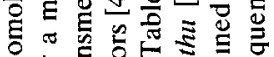

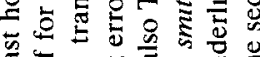

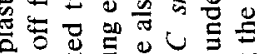

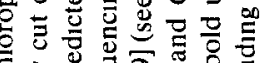

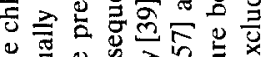

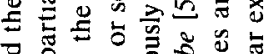

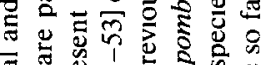

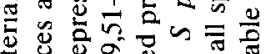

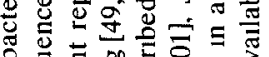

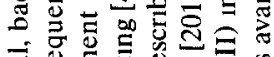

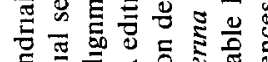

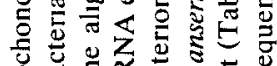

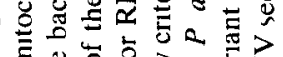

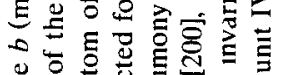

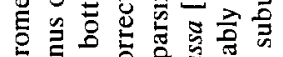
है

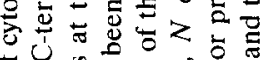

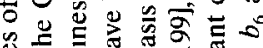
政

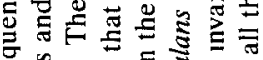

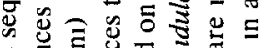

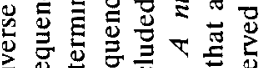

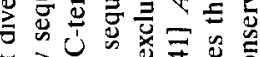
突记守宇

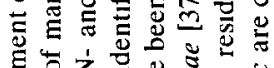

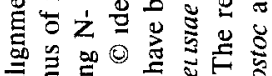

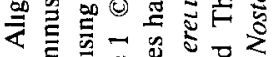

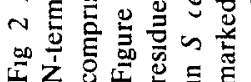


seen, except for a subunit of Sulfolobus quinol oxidase [70], in other diheme membrane cytochromes (e g, cytochrome $b-558$ of $E$ coll nitrate reductase [71] or the largest subunit of cytochrome oxidase [70])

\section{IV-B Limitations of sequence analysis and mutagenesis}

The conserved residues in cytochrome $b$ sequences are obvious targets for mutagenesis experiments aimed to understand their possible functional role $[8,18] \mathrm{Re}$ cently, experiments in this direction have been carried out in two purple bacteria, $R$ sphaeroides by the group of T Crofts and R Gennis $[8,18,44,65]$ and $R$ capsulatus by the group of $\mathrm{F}$ Daldal and L Dutton $[19,68,69]$ The results indicate that only a few of the evolutionary conserved amıno acids seem to be essential for function of the $b c_{1}$ complex as measured in the bacterial membrane preparations $[8,18,68,69]$ Note, however, that the interpretation of results obtained by site-directed mutagenesis may be ambiguous when no clear change in measurable properties is seen $[18,72,73]$

Conversely, the mutated amino acids may not be so important as anticipated by sequence conservation In the case of a few amıno acids, "evolutionary invariance does not necessarily imply functional invariance" [59], as indicated by analysis of cytochrome $c$ mutants This conclusion may be extended to cytochrome $b$ to explain, at least in part, why the mutation of invariant residues does not impair function $[8,18]$ However, catalytically or functionally non-essential residues may appear to be invariant due to the intrinsic limitations of sequence comparison One clear limitation is the phylogenetically uneven representation of the species that have been analyzed For instance, the phylogenetic series of both cytochrome $c$ (see Ref 59) and cytochrome $b$ (Table I) contain too few sequences from taxa of early evolutionary history (e g, lower metazoans) relative to the large number of sequences from vertebrates Consequently, it is likely that natural var1ants of 'invariant' residues have not been detected A second limitation of sequence comparison is its inherent assumption that the protein sequences are linear arrays of independently variable sites upon which natural selection acts uniformly This assumption oversimplifies the complexities of protein structures $[34,59]$ The structural flexibility of proteins enables them to accomodate the unusual substitution of important resıdues by backbone adjustments or by compensations at other sites that are close in the three-dimensional structure but distant in the primary sequence $[34,39,59,74-76]$

When considerıng the evolutionary conservation of gene sequences, one should not ignore the possibility that DNA features might have been preserved independently of the phenotypic properties of the coded protein $[77,78]$ This may be the case for the non-func- tronal but clearly homologous genes of cytochrome $b$ that have been discovered recently in nuclear DNA [79] Conversely, one must be aware also that amıno acid residues that are crucial for function may not be evolutionary invariant in protein sequences [59] In cytochrome $b$, examples are residue 143 for a photosynthetically-deficient mutant in Rhodobacter $[19,68]$ and several residues such as 133 for yeast respiratory deficient mutants (see Ref 76 and references therein)

\section{III-C The most and least conserved regions in cy- tochrome $b$}

The boundaries of the conserved domains in cytochrome $b$ that were assigned previously $[6,27,33]$ are largely confirmed in the current alignment of sequences (Fig 3) We have evaluated the different degree of conservation of the structural elements of the protein by measuring their average score of identity in the alignment of Fig 2 Among the transmembrane structures, helices $\mathrm{B}, \mathrm{C}$ and $\mathrm{A}$ are the most conserved (1dentity score of 063,062 and 059 , respectively), followed by helices $\mathrm{D}$ and $\mathrm{F}$ which have a score of 056 and 052 , respectively Helices $\mathrm{E}$ and $\mathrm{H}$ are the least conserved, with an identity score of about 04 Interest-

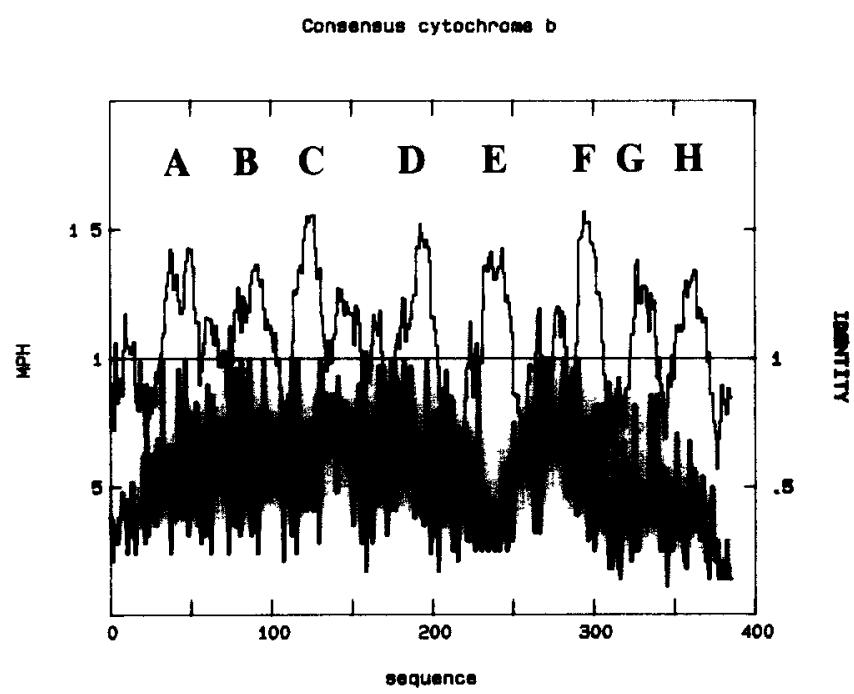

Fig 3 Hydropathy profile of the consensus sequence of cytochrome $b$ This consensus sequence has been generated by using the alignment of Fig 2 normalized to the yeast sequence (gaps or insertions have been excluded) and extended to the following sequences to increase the variation $K$. lactis [198], $C$ glabrata (G D Clark-Walker, personal communication), $N$ crassa [200], $A$ franciscana (R Garesse and F Marco, personal communication), $T$ brucet $[48,49], S$ purpuratus [45], $P$ gallinaceum [205], wheat [51,209], $R$ sphaeroides [44], $P$ denitrificans [218], the chloroplast subunits of $M$ polymorpha [226] and the $b_{6}$-like protein from Bacillus PS3 [82] The profile is calculated with the scale of membrane propensity for haemoproteins (MPH [94,95]) and a window of 7 residues The fractional identity of each position in the alignment (scale on the right of the graph) is represented by the thick-marked histogram without smoothing (skyline plot [35]) 
ingly, the profile of sequence identity does not vary significantly, etther qualitatively or quantitatively, by permuting or increasing the compared sequences of cytochrome $b$ except for the 100 residues towards the C-terminus The variability of this part of the protein is much larger than previously calculated $[6,11,27,28,36]$, because many more sequences can now be compared

There is an uneven distribution of conservation in the regions of cytochrome $b$ that are predicted to protrude at the two sides of the membrane, since only one third of the most conserved residues lie at the negative side (Table II and Refs 6, 27) One reason for this may be the requirement of proper protein-protein contacts between cytochrome $b$ and the 'Rieske' ironsulphur subunit which plays a major role in ubiquinol oxidation at the positive side of the membrane $[5,7,9,28,69,73,80,81]$

\section{$I V-D$ Cytochrome $b$ and evolution}

The occurrence of cytochrome $b$ genes in nearly all eukaryotic organisms and in diverse prokaryotes indicates an early appearance during evolution $[6,9,11]$ It is found both in Gram-negative and Gram-positive eubacteria $[9,82]$ and, though in a poorly conserved form, in one archaebacterium [70] Thus, the ancestral gene must have existed before the separation of the major lineages of prokaryotes [83] Speculations on the evolution of cytochrome $b$ proteins have suggested fusions of different ancestral genes [6,11,71] Since cytochrome $b$ appears to have changed rather slowly during evolution [11], it is a useful molecule for deducing phylogenetıc relationshıps among species [29-33] Although a few regions of cytochrome $b$ sequences tend to be more conserved [6], other regions exhıbit considerable variability ( $F_{1} g$ ) and thus are valuable for determinıng the phylogenetic distance among species $[6,29,33]$

The sequences of the bacteria $R$ rubrum and $B$ japonicum cytochrome $b$ proteins show the highest amıno acid identity and the minımal number of gaps or insert lons with respect to the proteins from algae and plants (Fig 2) Cytochrome $b$ of $R$ rubrum shows as much, or more, sequence identity to that of plant mitochondria (587\% with liverwort) than to that of $R$ capsulatus (less than $57 \%$ identity), a purple bacterium belonging to a different phylogenetic group from $R$ rubrum [83] This is consistent with other studies on the origin of mitochondria from purple bacteria (see $[83,84]$ and references therein)

We note that among the gaps that are required for maximal matching of the sequences of cytochrome $b$ (Fig 2), that at yeast position 110-112 is shared by all metazoans and only one phylum of protozoans, the apıcomplexa like Plasmodium This difference might be related to the separation of the anımal lineage from the vegetal/fungal lineage If this hypothesis is valid, cytochrome $b$ would retain in its sequence some features that are related to the early evolution of eukaryotes

Some of the considerations just discussed led the group of Allan Wilson to use the gene of mitochondrial cytochrome $b$ for establishıng phylogenetic relationships among anımal species [29-32], an approach which has been extended by many other investigators [3133,60-62,64,85-91] As for any other macromolecule used for such studies, cytochrome $b$ offers both advantages and disadvantages (see Ref 89 for a review) One disadvantage is the limited part of the cytochrome $b$ sequence that is analyzed, since most studies have focused only on the region spanning helices A to C (Fig 1 and Refs 29-31, 64, 85-91) This particular region exhibits a high degree of conservation (Figs 1 and 3 ) and thus offers a limited set of allowed changes that hampers resolution of close relationships among species $[30,64,89]$ The full potential of cytochrome $b$ for the study of molecular phylogenetic relationships has not yet been exploited because its most variable regions, e g , that spanning residues 210 to 250 (Fig 3), have not been studied in detall except for groups of mammals [32], bırds [33,91] and fish $[90,180]$

\section{Structural deductions of cytochrome $b$ from se- quence analysis}

\section{V-A Hydropathy profiles}

Current knowledge of the structure of cytochrome $b$ is derived mainly from predictions of secondary and tertıary structure based upon primary sequences Since cytochrome $b$ is a very hydrophobic proten spanning the lipid bilayer [1,3-6,9,12], methods of evaluating hydrophobicity (or hydropathy [92]) have been used to predict its transmembrane folding [10,12,22-25,27,28, 71,92-97] The method of Kyte and Doolittle [92] was used initially for analyzing sequences of cytochrome $b$ proteıns [22,23] and nune transmembrane $\alpha$-helices were predicted for mitochondrial cytochrome $b[22,23]$ Subsequently, other approaches were uttlized by Crofts [24] who proposed that the fourth helix did not span the membrane This eight-helıx model for cytochrome $b$ is now widely accepted $[5,6,8,9,12,19,73,76,94,98]$, primarily because it is consistent with the location of mutations producing resistance to center $\mathbf{1}$ and center $\mathbf{o}$ inhıbıtors $[6,19,24-28,73]$ Structural deductıons by statistical methods of hydropathy [28,93-95], and exper1mental studies of membrane topology $[8,12,21,36,65,98]$ sustain the same model

The topology of the C-terminal part of cytochrome $b$ comprising helices $\mathrm{G}$ and $\mathrm{H}$ is unclear Since subunit IV of chloroplast $b f$ complex, homologous to the Ctermınal domain of cytochrome $b[11,12,23]$, lacks helix 
H (cf Fig 2), it has been suggested that mitochondrial cytochrome $b$ may also be folded in seven transmembrane helices [12,99] However, homologous subunits of redox complexes belonging to the same superfamily can have a different number of transmembrane helices as occurs for the largest subunits of quinol oxidase and of cytochrome $c$ oxidase [70] Moreover, extensive hydropathy analyses of the mitochondrial sequences ( $\mathrm{F} 1 \mathrm{~g}$ 4 A, cf Refs $8,27,90,94,95)$ consistently indicate the transmembrane character of helix $H$ Helix $G$, rather than helix $\mathrm{H}$, is the most weakly predicted of the eight putative transmembrane helices of cytochrome $b$ (Fig 3 and $4 \mathrm{~A}$, and data not shown) Nevertheless, the average hydropathy profile of cytochrome $b$ sequences trom the most diverse species shows that helices $G$ and $H$ have similar hydrophobicity, to each other and to other transmembrane helices (Fig 4B) We continue to support, therefore, the eight-helix model for mitochondrial and bacterial cytochrome $b$ proteins [24,26,19,28, $73,76,94,98]$

No hydropathy method is satisfactorily accurate in predicting the terminı of transmembrane $\alpha$-helices [93-95,100,101] Consequently, significant differences in the prediction of these termin in cytochrome $b$ have been reported depending upon the sequences analyzed and upon the method employed $[9,11,22,24,25,70,73$, $76,90,93,94,96]$ An improved procedure for predictıng the termini of transmembrane helices is important for further deductions of cytochrome $b$ structure $[25,28,90]$ and we have therefore utılized several approaches to tackle this problem These include (1) comparison of the hydrophobicity profile of each sequence to the average hydropathy $[40,94]$ of the most diverse species (Fig 4B), (11) location of the gaps in the alignment that maximize the homology with multiple sequences and overlap the regıons containıng intron-exon junctıons, which generally occur in extrinsic loops [35,39,40,97], (111) similarity in the sequence motifs with the known transmembrane helices in the bacterial reaction centers $[36,71,73,90,101-104]$, and (1v) spectroscopic information on the membrane topology of the $b$ hemes $[7,36,105,106]$ The termını of the transmembrane helices that resulted from the integration of the above approaches are shown in Figs 1 and 2 and differ, considerably in some cases, from those suggested previously $[6,11,18,21-27,70,73,76,94,96-99]$ In particular, both helices $B$ and D are extended three helical turns after the histidine ligands of the $b_{\mathbf{H}}$ heme, because this heme appears to be deeply embedded within the membrane dielectric $[105,106]$ and a conserved GS/GG motıf is seen at the C-terminus of both helices $[36,90]$ (Figs 1 and 2) Indeed, similar doublets of small residues, such as SS, GS and AT, are found at the termını of transmembrane helices in the photosynthetic reaction center [101-104]

\section{$V-B$ Periodicity in the transmembrane helices}

Given that the $\alpha$-helix is the dominant conformation observed [21] and predicted in cytochrome $b$ proteins [24-28], the periodicity profile approach of Eisenberg [107] may provide insights into the structure of cytochrome $b$ The profile of the helical periodicity of residue hydrophobicity can detect amphipathic $\alpha$ helices [107,108] Helical periodicity can be analyzed also by generatıng a profile of the amıno acid varıabılity (or mutability) moment of the residues in aligned sequences $[28,102,103,108]$ In the structure of the bacterial reaction center [101-104], the least conserved residues of the transmembrane helices face the lipids whereas the most conserved residues of the same helices face the interior of the proten Hence, the maxima in the profile of the variability moment of membrane proteins correspond to helices exposed to the solvent, which can be either transmembrane helices largely surrounded by lipıds or amphipatic helices $[103,108]$ The variability moment does not depend on a subjective choice of the hydrophobicity scale as does the hydrophobic moment $[100,109]$, but only on the correctness of the alignment of the sequences $[40,108]$

Eisenberg and coworkers have applied the combined profile of the hydrophobic and variability moments [108] to the alignment of cytochrome $b$ sequences reported by Hauska et al [11] This analysis indicated that helices A, C, F, G and loop cd (that was considered transmembrane) had strong varidbility moments [108] Our alignment of Fig 2 is substantially different from that of Hauska et al [11] and includes a much wider set of phylogenetically different sequences (cf Fig 2 and Ref 11) Hence, the periodicity analysis of the present alignment may provide further insights into the helical structures of cytochrome $b$ Helices $\mathrm{A}$, $\mathrm{B}$ and, to a lesser extent, $\mathrm{F}$ and $\mathrm{H}$ show maxima in the profile of variability moment (data not shown) that are indicative of a lipıd-exposed nature of one side of their transmembrane sector The differences from previous analysis $[28,108]$ derive from the more diverse set of sequences used here

The profile of amphipathy of cytochrome $b$ sequences shows features that are often coincident with those of the variability profile, especially for the sharp maxima in loops ab, cd and ef (Fig 4B and Refs 8, 28, 108) The regions around these maxima (at residues $63-65,154-158$ and 262-265, Fig 4B) are predicted to have also a strong propensity for $\alpha$-helux conformation (results not shown) Therefore, it is feasible that such regions of cytochrome $b$ may form short amphipatıc helices similar to those in the bacterial reaction center [101-104] Indeed, the same computer analysis as that in Fig 4B indicates that the extrinsic helices ab, cd, de and $e$ in the $L$ subunit of the reaction center are 
associated with local maxima of the periodicity profiles (results not shown and Ref 103)

We introduce here an alternative method of evaluat-
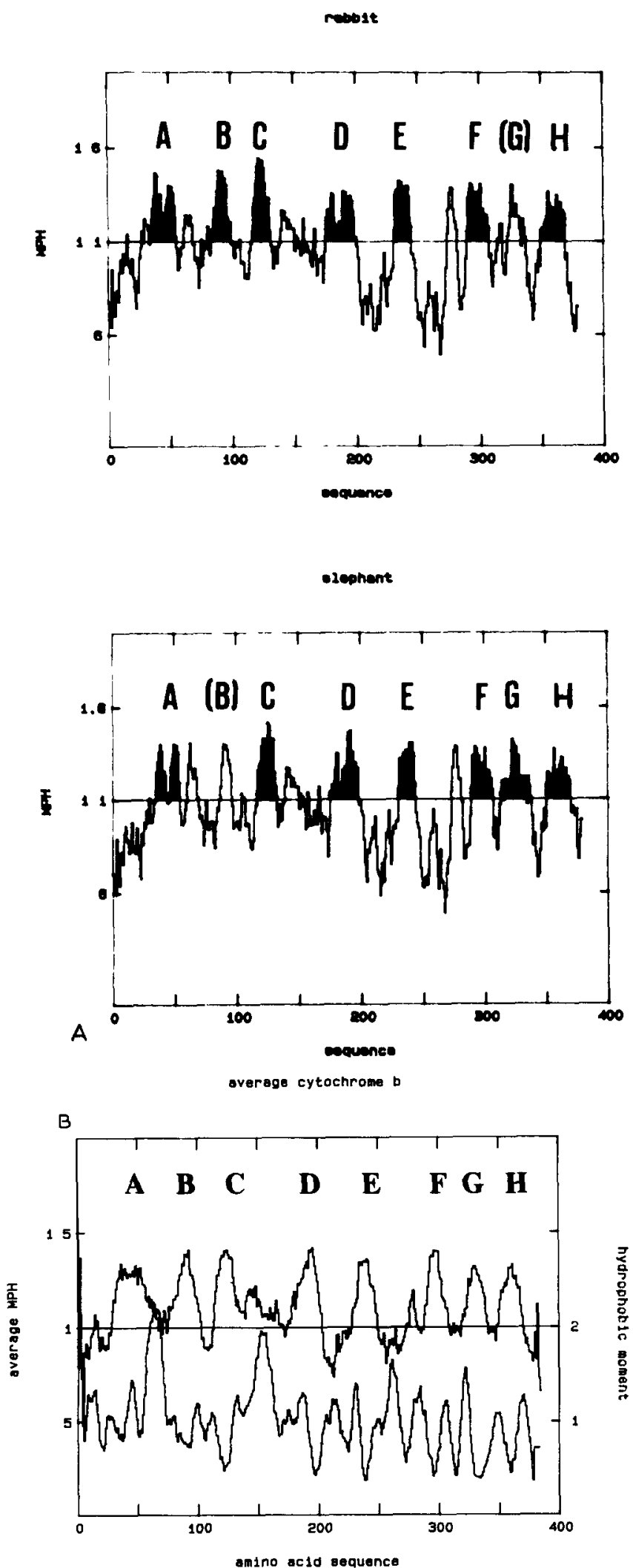

Ing the amphipatic conservation of the residues along the transmembrane helices of cytochrome $b$ (Fig 5) In the helical-wheel representation we have inserted the
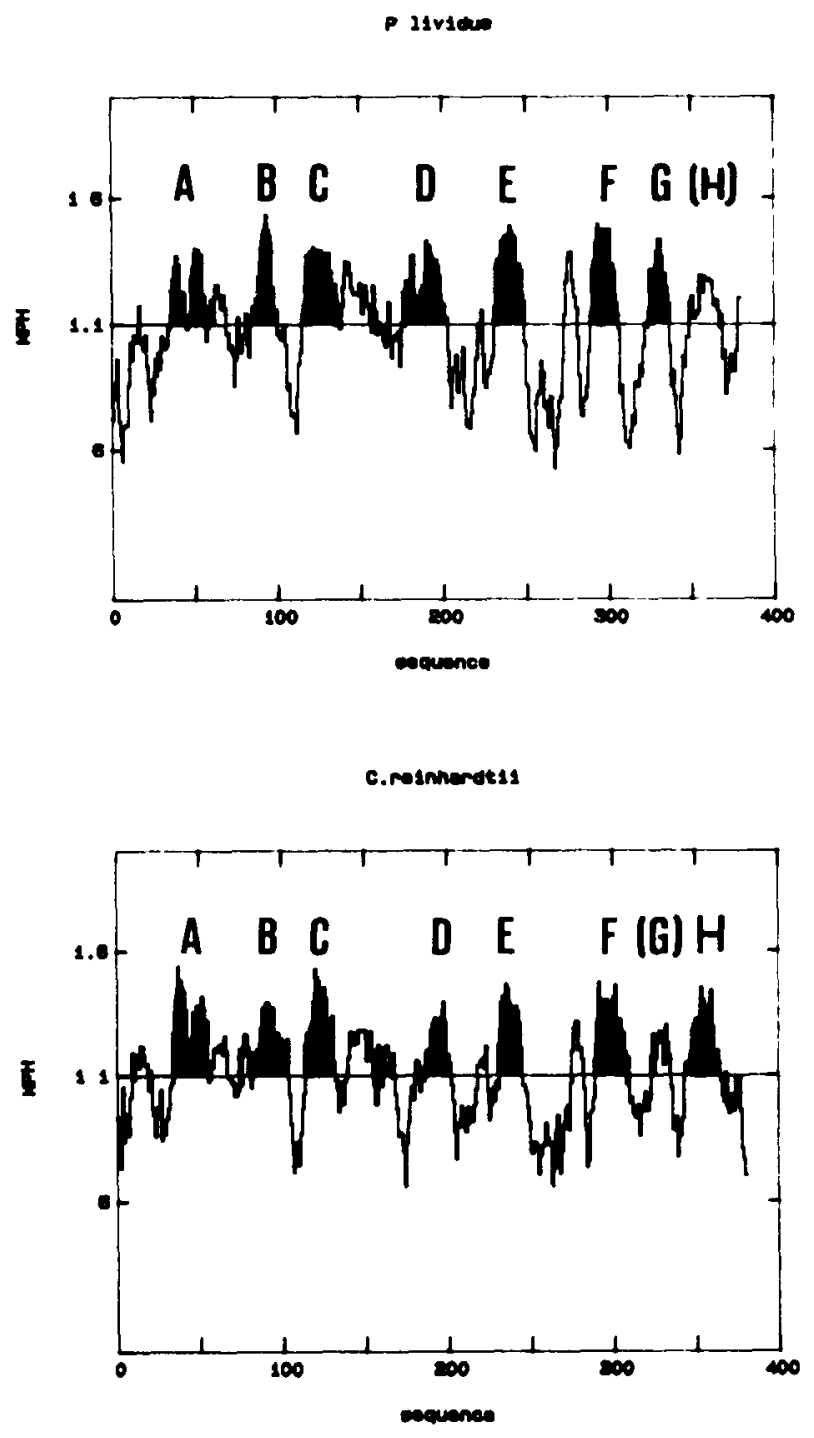

Fig 4 (A) Hydropathy profile of four representative sequences of mitochondrial cytochrome $b$ The procedure is the same as in Fig 3 The peaks painted in black are the regions which are predicted to form transmembrane helices $[94,95]$ Note that helix G falls to do so in the rabbit and $C$ reinhardtu proteins (the same is true in 15 other sequences), whereas helı $\mathrm{H}$ is not predicted to be transmembrane in $P$ lividus (the same is true in fly, mouse, and $C$ glabrata) Helix B is not predicted in the elephant protein using the MPH scale. but it is often not predicted with the Rao-Argos [93] scale as in Ret 95 See Table $I$ for the references of the sequences (B) Profile of average hydropathy and amphipathy of diverse cytochrome $b$ sequences The average hydropathy, according to the MPH scale [94,95], was calculated as described in Ref 108 with the alıgnment of Fig 2 and corresponds to the thick profile in the upper part of figure The profile of hydrophobic moment or amphipathy of the protein (lower part of the figure) was derived from the computation of the average hydropathy of the alıgned residues as in Refs 107, 108 The sequence analysis and plots were obtained with a sliding window of 11 residues and programs developed by $\mathrm{M}$ Crımı 


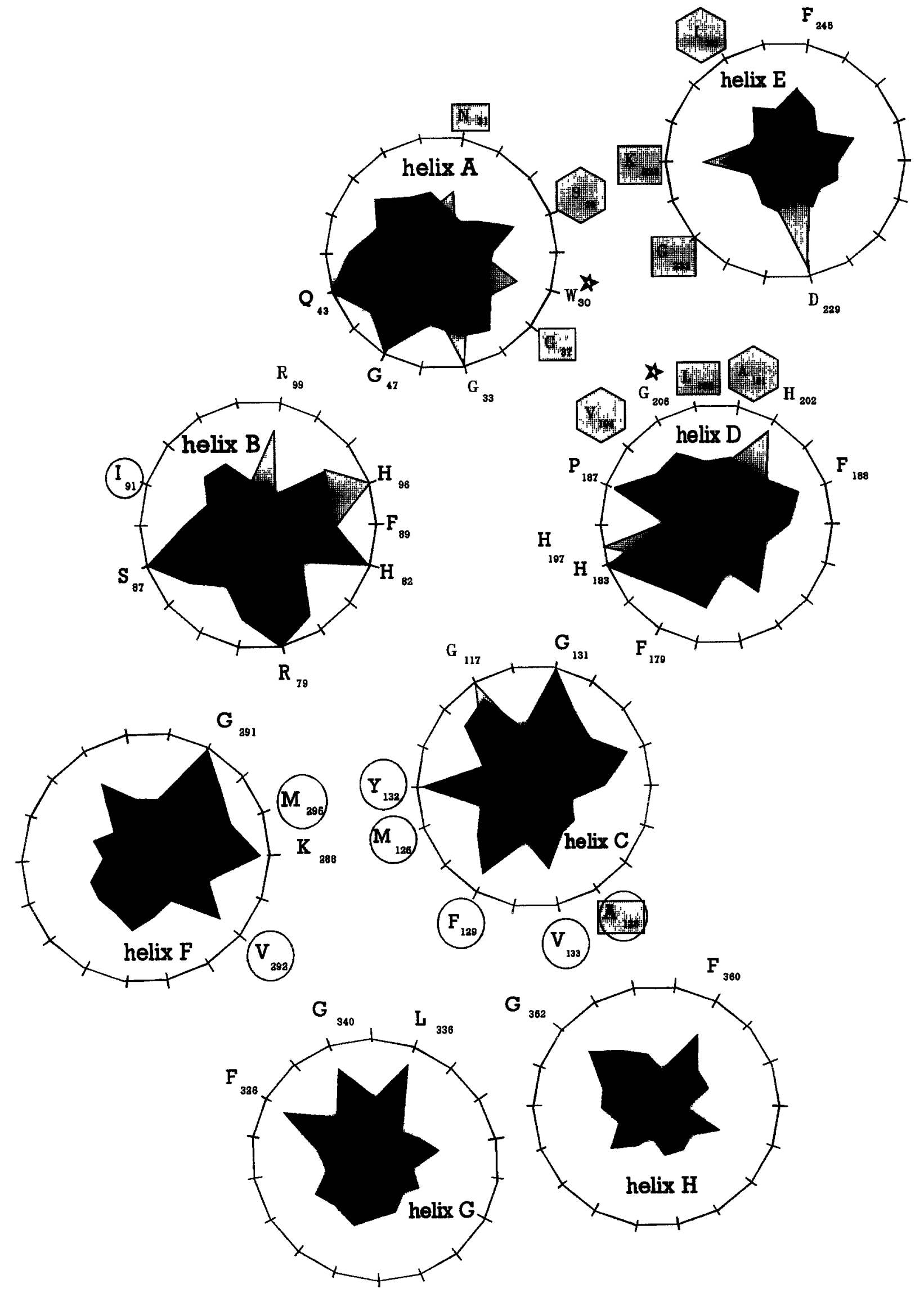


degree of conservation per each position, which defines an area (black in the figure) indicating the 'conserved sequence section' of the helix viewed from the positive side of the membrane The positions that have greater sequence conservation at the negative side, rather than at the positive, of the membrane are indicated by a lighter shading Additionally, the residues involved in the binding of the inhibitors of the $b c_{1}$ complex (see later, Tables III, IV and V and Refs 8, 19, 26, 36, 73, 76) are also marked in the drawing (Fig 5) It appears from this representation that conserved residues tend to cluster at one face of the transmembrane helices, particularly near the positive side of the membrane (Fig 3 and data not shown) Contrary to the other helices, helıx $\mathrm{E}$ has a conserved quadrant only at the negative side of the membrane (Fig 5)

The mode of packing of the helices can be deduced by maximızing the contacts between the most conserved faces, which are likely to be involved in intramolecular protein-protein interactions, and by considering the predictions from the periodicity profiles $[8,18,34,103,108]$ The tentative packing of the helices in Fig 5 is bult with these features in mind and by using the transmembrane helices in the structure of the bacterial reaction center as a model The hypothetical model presented recently by Crofts and coworkers $[8,18]$ shows a disposition of helices $A$ to $F$ that is quite similar to that in Fig 5

\section{Structure versus function in cytochrome $b$} VI- $A$ The paradigm of the photosynthetic reaction cen-
ters

The techniques of sequence analysis that have been discussed thus far are of limited value for understanding the detals of the redox function of cytochrome $b$ since no atomic structure is avallable, although crystalization of the beef $b c_{1}$ complex has been reported $[110,111]$ Complementary information is indispensable for refinements of the present models of mitochondrial cytochrome $b$ structure This information is also important for understanding the function of structural features that are conserved $[8,18,19,65,68]$

Important relatıonshıps can be establıshed indirectly between the structural features of cytochrome $b$ and the sensitivity of the $b c_{1}$ complex to its inhibitors $[5,6,8,9,12,19,24-28,36,39,44,46,68,73,80,81,90]$ This is possible because the inhibitors of the $b c_{1}$ complex bind directly to cytochrome $b$ as evidenced by photoaffinity labelıng [17], changes in spectroscopic properties $[80,81,112-115]$ and genetic analysıs $[4-6,19,24,26,36$, $68,73,81]$ These inhibitors basically act as analogs of ubiquinone, ubiquinol or ubisemiquinone at either center $\mathbf{i}$ or center o $[5,6,9,19,24,26,36,68,73,81,112-114]$, therefore, they are similar to the quinone antagonists

Fig 5 Conserved regions or segments of the putative transmembrane helices of cytochrome $b$ viewed from the positive side of the membrane The hypothetical arrangement of the helices derives from a scheme discussed previously by Tron [157] The conserved segments of the helices are obtained by summing the fractional identity at each amıno acid position (calculated as in Fig 3 and normalized to the radius of the helical circle) in the 18 sectors of 20 degrees into which the wheels are subdivided The areas shaded in darker tone correspond to residues occurring from the positive side to the middle of the membrane The residues that are more conserved at the negative than at the positive side of the membrane are represented by the areas with lighter shading The periodicity of the residues is assumed to conform to that typical of $\alpha$-helices, as generally confirmed by the power helical analysis described in Refs 102, 103 (results not shown) Only helix D is considered to be bent in view of the presence of P187 [94,157,159] Modeling of yeast cytochrome $b[157]$ indicates that the two histidine ligands in helıx D could be positioned nearly on top of each other, thus confirming previous suggestions of $\mathrm{a} \approx 140^{\circ}$ displacement between position 187 and position 188 as a consequence of the prolıne-bent [159] Key conserved residues of each helix are reported and they correspond to the consensus sequence normalized to yeast (Fig 2) Residues enclosed by a circle are involved in the binding of center o inhibitors (Table IV) Residues enclosed in a light-grey square are involved in the binding of center 1 inhibitors (Table III and Fig 1) Residues enclosed in light-grey hexagons are tentatively considered to be responsible for natural resistance towards center 1 inhibitors (Table V and see text) The stars identıfy positıon 30 (helix A) and 205 (helix D) that may show compensatory exchanges in some protozoans (Fig 2 and see text) Note also that the directed mutation of the H202 and D229 residues produces weakenıng of antımycin binding in Rhodobacter [8] The packıng of the helices has been modeled by maximızıng the contacts between their most conserved faces and by considering that their least conserved faces are likely to be exposed to the lipids of the membrane [103,108] It was assumed that only intramolecular protein-protein contacts are responsible for the sidedness in the sequence conservation of the helices even If it is possible that some of them may contact the single transmembrane helix of cytochrome $c_{1}$ or of other nuclear subunits withın the reductase complex [9] Given that the aligned sequences of cytochrome $c_{1}$ and $f$ indicate a conservation quadrant of the membrane helix at the positive side of the membrane (results not shown) and that one site of interaction between cytochrome $c_{1}$ and cytochrome $b$ has been found in loop cd [69], it might be speculated that the transmembrane contacts between these proteins occur at either the corner between helices $A$ and $B$ or at that between helices $C$ and $D$ in the proposed model The same type of representation was bult with the aligned sequences of subunits $L$ and $D$, of photosynthetic reaction centers $[101,103]$ and used as a guide for packing together the helices of cytochrome $b$ at the negative side of the membrane (cf $[18,24]$ ) It was also considered that the eight helices could be organized in two layers as in other membrane proteins $[75,101,103,157]$ Note that the packıng of helices $\mathrm{G}$ and $\mathbf{H}$, for which no structure-function correlation is avalable so far, is chiefly based on the conserved sectıons derived from the alıgnment of Fig 1 and the periodicity profiles of variability and amphıpathy (data not shown) 
(herbicides) that bind to the $\mathrm{Q}_{\mathrm{B}}$ site in photosynthetic reaction centers $[8,19,24,71,73,101,116-121]$ Several compounds are inhibitors of both the photosynthetic systems and cytochrome $c$ reductase hydroxy quinoline $N$-oxıde (HQNO), diuron, 6-undecyl-5-hydroxy2,3-dioxobenzothiazole (UHDBT), stigmatellin and myxothiazol $[113,117,121-123]$ Furthermore, reactions at center $\mathbf{i}$ of the $b c_{1}$ complex such as semiquinone stability are similar to those of the photosynthetic $Q_{B}$ site $[7,24,28,73,106,115,117,124,125]$ Additionally, mutants resistant to inhibitors are avallable for both the photosynthetic systems (reviewed in Refs 116-118, 120 ) and cytochrome $b$ (see below and Refs 6, 9, 19, $24,26,36,73$ )

TABLE III

Sensitult points towards center $\mathbf{i}$ inhibutors

\begin{tabular}{|c|c|c|c|c|c|c|c|c|}
\hline \multirow[t]{2}{*}{ Residue } & \multirow[t]{2}{*}{ Change } & \multirow[t]{2}{*}{ Species } & \multirow[t]{2}{*}{ Ref ${ }^{4}$} & \multicolumn{4}{|c|}{ Relative inhıbitor titre $\left(I_{50}\right)^{\mathrm{b}}$} & \multirow[t]{2}{*}{ Notes } \\
\hline & & & & Antımycin & Funıculosın & HQNO & Diuron & \\
\hline 117 & $\rightarrow \mathrm{F}$ & $S$ cerevistae & [26] & 1 & 1 & yes & yes & [129] \\
\hline N31 & $\rightarrow \mathrm{K}$ & $S$ cerevisiae & {$[129,234]$} & 1 & 06 & 19 & 20 & {$[133] \mathrm{d}$} \\
\hline N31 & $\rightarrow \mathrm{K}$ & $K$ lactss & {$[130]$} & yes & - & 67 & 32 & {$[132] \mathrm{e}$} \\
\hline $\begin{array}{l}\text { N31 } \\
\text { I44 }\end{array}$ & $\left.\begin{array}{l}\rightarrow \mathrm{K} \\
\rightarrow \mathrm{T}\end{array}\right\}$ & $K$ lactıs & [130] & yes & - & - & 1 & {$[132] \mathrm{e}$} \\
\hline \$34 & $\rightarrow \mathrm{F}$ & & & & & & & \\
\hline $\begin{array}{l}\text { G37 } \\
\text { G232 }\end{array}$ & $\left.\begin{array}{l}\rightarrow \mathrm{F} \\
\rightarrow \mathrm{N}\end{array}\right\}$ & Paramecuum * & [56] & 45 & $>2000$ & 22 & $\geq 1$ & {$[39] \mathrm{f}$} \\
\hline G37 & $\rightarrow \mathrm{V}$ & $S$ cerecustae & {$[26,235]$} & $16(4)$ & $5(4)$ & (11) & $(03)$ & {$[129] \mathrm{g}$} \\
\hline G37 & $\rightarrow \mathrm{V}$ & $M$ musculus & [134] & $<1000$ & $<100$ & 26 & - & $\mathrm{h}$ \\
\hline A37 & $\rightarrow \mathrm{V}$ & $S$ pombe & [131] & yes & - & - & ves & - \\
\hline$A 37$ & $\rightarrow \mathrm{G}$ & $S$ pombe & [131] & yes & - & - & yes & - \\
\hline $\begin{array}{l}\text { G37 } \\
\text { A61 }\end{array}$ & $\left.\begin{array}{l}\rightarrow \mathrm{V} \\
\rightarrow \mathrm{V}\end{array}\right\}$ & $S$ cereiustae & {$[26,235]$} & yes & - & - & - & {$[129]$} \\
\hline$A 126$ & $\rightarrow \mathrm{T}$ & $S$ cereustae & {$[91,141]$} & (1) & (2) & - & - & $f$ \\
\hline L198 & $\rightarrow \mathrm{F}$ & $S$ cereutsiae & {$[136]$} & (15) & $8(2)$ & (5) & $(07)$ & $\mathrm{e}$ \\
\hline $\begin{array}{l}\text { S206 } \\
\text { N208 }\end{array}$ & $\left.\begin{array}{l}\rightarrow \mathrm{L} \\
\rightarrow \mathrm{Y}, \mathrm{K}\end{array}\right\}$ & $S$ cereutsiae & [156] & 1 & $5-7$ & 12 & 1 & 1 \\
\hline $\mathrm{F} 225$ & $\rightarrow \mathrm{S}$ & $S$ cerevistae & {$[129,234]$} & 1 & 3 & 24 & 20 & [133]d \\
\hline $\begin{array}{l}\mathrm{F} 225 \\
\mathrm{I} 226\end{array}$ & $\left.\begin{array}{l}\rightarrow \mathrm{L} \\
\rightarrow \mathrm{F}\end{array}\right\}$ & $S$ cerevisiae & {$[26,234]$} & 1 & 06 & 9 & 17 & {$[133] \mathrm{d}$} \\
\hline $\mathrm{K} 228$ & $\rightarrow \mathrm{M}$ & $S$ cerecisiae & {$[26,236]$} & 7 & 1 & - & - & {$[235] \mathrm{g}$} \\
\hline $\begin{array}{l}\text { K228 } \\
\text { deletion230) }\end{array}$ & $\rightarrow \mathrm{M}$ & $K$ lactis & {$[130]$} & yes & - & - & 1 & [132] e \\
\hline $\left.\begin{array}{l}\text { deletion } 231 \\
\mathrm{~T} 232\end{array}\right\}$ & $\rightarrow \mathrm{S}$ & $K$ lactts & {$[130]$} & yes & - & 30 & 2 & {$[196] \mathrm{e}$} \\
\hline G232 & $\rightarrow \mathrm{D}$ & $M$ musculus & [128] & $2-14$ & 10 & 21 & - & {$[135] \mathrm{f}$} \\
\hline $\mathrm{G} 232$ & $\rightarrow \mathrm{N}$ & $A$ suum * & [54] & yes & - & 5 & - & {$[127] d$} \\
\hline $\begin{array}{l}\mathrm{G} 232 \\
\mathrm{~A} 194\end{array}$ & $\left.\begin{array}{l}\rightarrow \mathrm{T} \\
\rightarrow \mathrm{V}\end{array}\right\}$ & $S$ cerelısiae $*$ & & 1 & 6 & 1 & 01 & {$[90] \mathrm{f}$} \\
\hline
\end{tabular}

a Original reference describing the isolation and/or sequencing of the mutants and their properties with regard to inhibitors resistance

$b$ The relative titre of the inhibitor is the ratio between the $I_{50}$ in the mutant and that of the wild type or of sensitive species after normalization to equivalent contents of cytochrome $b$ [36] 'Yes' indicates that resistance has been observed without any quantitative data being reported, whereas the dash indicates that no information is avalable When several mutants carrying the same genotipic mutations have been reported, data are shown only for one of them Number in parenthesis are the titres obtained in the specific assay of mitochondrial ubiquinol cytochrome $c$ reductase measured as described in [36,39,46] (Tron, T, Ghell, A, Coppèe, J Y, Colson, A M, Bruel, C, Lemesle-Meunier, D and Deglı Espostı, M, unpublished data) Note that different titres are often obtained for the same mutant depending upon the type of assay employed [132,135,237] The list does not include the yeast respiratory deficient mutant M221 $\rightarrow$ L, which binds antımycin with low affınity [150], and mutants recently obtained in bacterıa (A Trebst, personal communication and Refs 8,69 )

Additional reference and type of assay employed for the data shown

d Assay of NADH respiration of mitochondria [133]

c Assay of succinate respiration in mitochondria [130,136]

t Assay of the ubiquinol-2 cytochrome $c$ reductase in isolated mitochondria $[39,90]$ Species considered to be naturally resistant to one or more inhibitor (see text and also $[36,39,90]$ ) are marked by an asterisk These data and those in parenthesis are directly comparable with the levels of natural resistance obtained here (Table V)

s Assay of ethanol respiration in whole cells [235] Clear discrepancies between the inhibitor titrations obtained in this type of assay and those at the mitochondrial level are commonly seen in yeast mutants (cf $[130,237]$ )

h Assay of succinate cytochrome $c$ reductase [134] 
The similarities in quinone redox chemıstry and protein topology of the resistance loci suggest that the structure of the quinone-binding sites of the bacterial reaction centers may be a valuable model for the quinone reacting sites in cytochrome $b[8,24,28,36,71$, $73,124,125]$ In particular, by analogy with the resıstance to herbicides in plants and photosynthetic bacteria [116-120], it is likely that the inhibitor resistance loc1 in cytochrome $b$ contribute to the structure of the quinone binding sites $[5,6,9,12,18,19,24-28,36,68,73$, $81,115]$

One difficulty in extrapolatıng the present information on herbicide resistant mutants to inhibitor resistance mutants in cytochrome $b$ regards the differences between the $Q_{B}$ center and center $\mathbf{o}$ [115] Whereas center $\mathbf{i}$ is formed structurally from cytochrome $b$ alone [9], as the $L$ subunit forms the $Q_{B}$ site $[101,103,120]$, center $\mathbf{O}$ is formed by cytochrome $b$ plus the 'Rieske' Iron-sulphur proten $[7-9,15,80,81,115,126]$ The latter is necessary for the oxidation of ubiquinol [7$9,80,81,113]$ and the binding of the inhibitor stigmatellın [126] Moreover, at center o there seem to be two sites for inhibitors [115,126] and possibly for ubıquinone/ubiquinol as well [81]

\section{VI-B Cytochrome $b$ residues involved in binding of cen- ter 1 inhibitors}

Functionally, the center $\mathbf{i}$ inhibitors block the reoxidation of cytochrome $b$ and destabilize the bound ubısemıquinone $[8,9,80,106,125]$ Antımycin is the most powerful of these compounds (see Ref 113 for a review), but it is by no means a universal inhibitor This antibiotic, in fact, is not potent in the $b c_{1}$ complex of parasitic nematodes [127] and of the protozoan $T e$ trahymena [39], and quite ineffective in chloroplast $b f$ complexes [3,121]

Table III lists all known mutations affecting the sensitivity towards center $\mathbf{i}$ inhibitors in mitochondrial cytochrome $b$ The mutated residues consistently lie within transmembrane helices $\mathrm{A}, \mathrm{D}$ and $\mathrm{E}$ and lead to an increase in the volume of the exchanged residue (Fig 2 and Table III, cf Refs 6, 8, 12, 90, 128-136) With the exception of the mouse mutant G232 $\rightarrow$ D [135], the mutations do not significantly alter the turnover of the reductase and, in general, produce a limited increase in the titre of the inhibitors (Table III and $[26,128-136])$ These properties of the mutations leading to resistance towards center $\mathbf{i}$ inhıbitors are similar to those exhibited by the herbicide-resistant mutations that map within the transmembrane helices of the photosynthetic subunits [116-118] Such simılar1ties are useful for suggestıng which amıno acid residues confer natural resistance towards center $\mathbf{i}$ inhibitors $[19,39,90]$ Antımycin resistance in Paramecium (Table III of Ref 39), for instance, is likely due to the dramatic increase in volume side chain by the substitution G37 $\rightarrow$ F of cytochrome $b$ (Fig 2 cf Refs 39, 56) The same substitution is seen in some $b_{6}$ sequences ( $\mathrm{F}_{1 \mathrm{~g}}$ 2) In addition, the chloroplast counterparts of cytochrome $b$ show replacements of other residues which induce resistance to antimycin in yeasts and mouse (namely N31 $\rightarrow \mathrm{C}, \mathrm{K} 228 \rightarrow \mathrm{N}$ and $\mathrm{G} 232 \rightarrow \mathrm{Y}$, Fig 2) Cumulatively, these substitutions are likely to contribute to the low sensitivity to antimycin $\left(I_{50} \simeq 10^{-9}\right.$ $M$ [121]) of the $b f$ complex $[6,19,26,73,134]$, but it should be noted that they also occur in some protozoan cytochrome $b$ proteins (Fig 2), in which the inhibitor has a much higher affınity $\left(I_{50}<10^{-9} \mathrm{M}\right.$ [39]) So, the replacement of $\mathrm{H} 202$, which is the only residue conserved in mitochondrial cytochrome $b$ but not in its chloroplast counterparts at the negative side of the membrane (Fig 2 and Table II), may be also involved in conferring the antımycin insensitivity of the $b f$ complex

VI-C Cytochrome $b$ residues involved in binding of center o inhubutors

A large variety of compounds act as center o inhibitors (see [113] for a review) Although they all block reduction of the 'Rieske' ron-sulphur protein and prevent cytochrome $b$ reduction in the presence of antımycin $[9,15,80,94,106,112-115]$, they can be subd1vided into three types depending upon their effect on the metal groups at center o [113] The methoxyacrylates, including myxothıazol, do not substantially alter the mid-point potential or the EPR line shape of the Rieske iron-sulphur cluster, but alter the electronic absorption spectra of the cytochrome $b$ hemes $[80,81$, 113-115] The hydroxyquinones, such as UHDBT, specifically alter the cluster and its redox equilibrium with cytochrome $c_{1}$ and ubiquinol $[9,73,81,113,114]$ The chromone inhıbitors, including stıgmatellin, alter both the EPR spectra and the midpoint potential of the iron-sulphur cluster, and the optical spectra of the cytochrome $b$ hemes (Refs 81, 113, 126 and references therein) The latter are universal center o inhibitors, since they are potent inhibitors of the the $b f$ complex $[12,121]$ as well as of the $Q_{B}$ site in photosynthetic reaction centers $[121,123]$

A detaled characterization of mutants resistant towards center o inhibitors is avallable from studies of both mitochondrial $[36,134,137,138]$ and bacterial systems $[8,19,44,68,69,73,81]$ (Table IV) The results indicate that different positions within the cytochrome $b$ protein are critical for the binding of myxothiazol and stıgmatellın Apparently, chloroplast bf complex is insensitive to myxothiazol but quite sensitive to stigmatellın $[3,121]$ This can be correlated with the fact that some mutations affecting myxothiazol sensitıvity in cytochrome $b$ resemble the natural substitutions in the 
chloroplast sequences (e g, F129 $\rightarrow$ V), whereas those affecting stigmatellin are not altered in the chloroplast sequences (e g, T148, Fig 2 and Refs 6, 19, 73, 134,
137) Hence, multiple sites for the binding of inhibitors may coexist at center $\mathbf{o}$, probably reflecting its complex quaternary structure $[9,36,73,81,113,115,126,138]$

TABLE IV

Sensitu it, points towards center o thhibitors

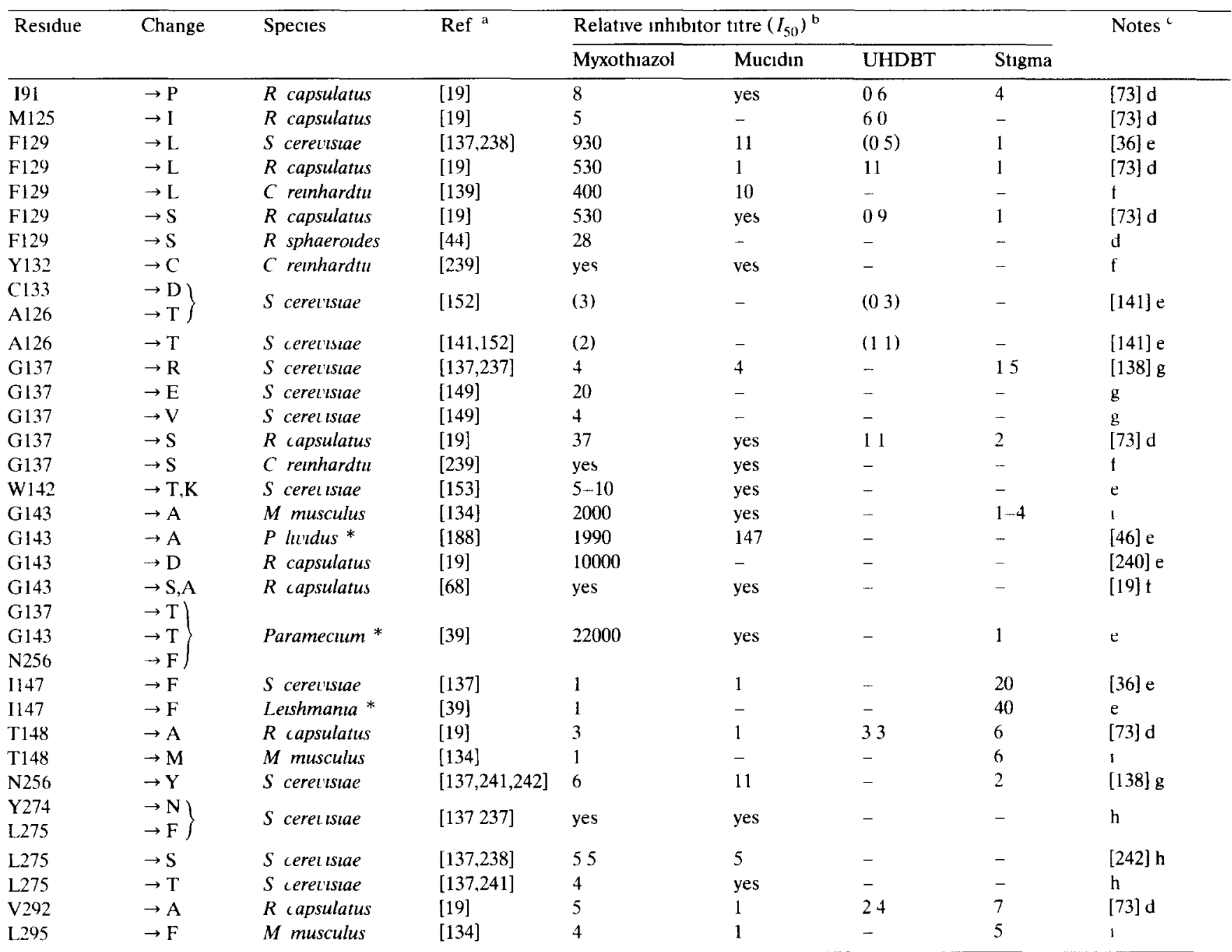

${ }^{1}$ Original reference describing the isolation and/or sequencing of the mutants and their properties with regard to inhibitors resistance

$\mathrm{h}$ The relative titre of the inhibitor corresponds to the ratio between the $I_{50}$ in the mutant and that of the wild type or sensitive species after normalization to equivalent contents of cytochrome $b$ [36] Yes' indicates that resistance has been observed without any quantitative data being reported, whereas the dash indicates that no information is avalable When several mutants carrying the same genotıpic mutations have been reported, data are shown only for one of them Numbers in parenthesis are the titres obtained in the specific assay of mitochondrial ubiquinol cytochrome $c$ reductase measured as described in [36,39,461 (Tron, T, Ghellı, A, Coppèe, J Y, Colson, A M, Bruel, C, Lemesle-Meumer, D and Deglı Espostı, M, unpublıshed data) Stıgma indicates both stıgmatellın and its tridecyl analog (cf [36])

( Additional reference and type of assay employed for the data shown

d Pre-steady-state assay with flash-induced reduction of cytochrome $b$ in bacterial chromatophores [44,73,106]

- Assay of the ubiquinol-2 cytochrome $c$ reductase in isolated mitochondria [36,39] Species considered to be naturally resistant to one or more inhibitor (see text and also $[36,39,90]$ ) are marked by an asterisk These data and those in parenthesis are directly comparable with the levels of natural resistance obtained here (Table $\mathrm{V}$ )

$t$ Assay in vivo based on cell growth $[19,139]$

8 Assay of succinate respiration of isolated mitochondria $[138,149]$

h Assay of NADH respiration in isolated mitochondria [237,238,242]

Assay of succinate cytochrome $c$ reductase [134] 
The positions affecting the sensitivity towards center o inhibitors are concentrated in two conserved domains of cytochrome $b$ ( $\mathrm{Fig}_{\mathrm{g}}$ ) The first domain spans helix $\mathrm{C}$ and the adjacent part of loop cd and contains twothirds of the resistance loci (Table IV and Refs 6, 19, $36,73,76,134,137,139)$ The beginning and the end of loop ef and the adjacent helix $F$ form the second domain $[6,19,73,134,137]$, where mutations show, in general, a level of resistance lower than those in the first domain (Table IV) Outside the above two domains there is the single bacterial mutant L91 $\rightarrow$ P, in which the altered amino acid lies in the middle of helix B $[19,73]$ Presumably because of this location, this mutant is affected in reactions occurring at the center 1 site [73] Contrary to the mutations conferring resistance to center $\mathbf{i}$ inhibitors (Table III), those inducing

TABLE V

Relattve tutre of inhtbutors of the $b c_{J}$ complex in different spectes

\begin{tabular}{|c|c|c|c|c|c|}
\hline \multirow{2}{*}{$\begin{array}{l}\text { Species and } \\
\text { preparation }{ }^{\text {d }}\end{array}$} & \multirow{2}{*}{$\begin{array}{l}\text { Cytochrome } b \\
\text { residues }{ }^{b}\end{array}$} & \multicolumn{4}{|l|}{ Relative $\mathrm{I}_{50}{ }^{\mathrm{c}}$} \\
\hline & & Funıculosın ${ }^{d}$ & HQNO $^{\mathrm{e}}$ & UHDBT $^{f}$ & $\overline{\text { Myxothıazol }}{ }^{g}$ \\
\hline Beef heart & M191 ${ }^{\mathrm{e}}$ & 1 & 23 & 1 & 12 \\
\hline Rat liver & - & 15 & 1 & 1 & 17 \\
\hline Pig liver & - & 14 & 20 & 08 & 1 \\
\hline Rabbit heart & V194 d & 60 & $\overline{20}$ & 13 & 11 \\
\hline $\begin{array}{l}\text { Horse heart and } \\
\text { Donkey heart }\end{array}$ & V194 d & $\overline{80}$ & 1 & 1 & 1 \\
\hline Chicken heart & T194 d & 10 & 11 & 1 & 09 \\
\hline Sturgeon liver & M126 dfg, F231 de & $\overline{21}$ & 28 & $\underline{2}$ & 36 \\
\hline Tilapia liver & $\mathrm{M} 126^{\mathrm{dfg}}, \mathrm{T} 194^{\mathrm{d}}$ & $\overline{75}$ & $\overline{14}$ & $\geq \overline{2}$ & $\overline{28}$ \\
\hline Drosophtla & ${\mathrm{L} 191^{\mathrm{e}}}^{\mathrm{e}}, \mathrm{T} 194^{\mathrm{d}}$ & $\frac{8}{8}$ & $\frac{21}{21}$ & -2 & $\frac{5}{12}$ \\
\hline Wheat germ ${ }^{h}$ & $\mathrm{G} 31^{\mathrm{e}}, \mathrm{V} 126^{\mathrm{dfg}}$ & $23 \overline{0}$ & $\overline{02}$ & $\underline{36}$ & 27 \\
\hline Paramecium & $\begin{array}{l}\text { F34 d }, \text { F37 de }, \text { V126 }{ }^{\text {dfg }} \\
\text { N232 de }, \text { L132 g }, \text { T137 } \\
\text { I142, T143 } \\
\text { g }, \text { F } 256^{\mathrm{g}}\end{array}$ & $\geq 3000$ & 220 & 2000 & 22000 \\
\hline $\begin{array}{l}\text { Crithidia or } \\
\text { Leishmanta }\end{array}$ & $\begin{array}{l}\text { F34 }{ }^{\mathrm{d}}, \mathrm{V} 126^{\mathrm{dfg}}, \mathrm{I} 191^{\mathrm{e}} \\
\mathrm{I} 194^{\mathrm{d}}, \mathrm{F} 231^{\mathrm{e}}, \mathrm{L} 232^{\mathrm{de}} \\
\text { T137 }^{\mathrm{g}}, \mathrm{M} 138^{\mathrm{g}}, \mathrm{S} 256^{\mathrm{g}}\end{array}$ & $\underline{6900}$ & 171 & $\underline{33}$ & 849 \\
\hline Rhodobacter & $\mathrm{I} 34^{\mathrm{d}}, \mathrm{V} 194^{\mathrm{d}}$ & 440 & 07 & 15 & 06 \\
\hline Rhodospirllum & M43 $\mathrm{fg}$ & - & - & 01 & 80 \\
\hline
\end{tabular}

${ }^{a}$ Mitochondria were prepared from heart, liver or whole organisms as described previously $[36,39,46,90]$ The concentration of the $b c_{1}$ complex was estımated by either the antımycin titre $[90,143]$ or from the content of cytochrome $b$ of the preparation $[36,39]$ The enzyme purified from Rhodobacter capsulatus Ga was kındly provided by N Gabellını and the data for the purıfıed enzyme from Rhodospirilum rubrum are taken from Ref [243]

${ }^{\mathrm{b}}$ Residues in the sequence of cytochrome $b$ that might be responsible for the alteration in the titre of one or more of the inhibitors (specified by the letters) These residues are hypothesized to be involved in inhibitor binding by d combination of sequence analyses (Fig 5 and Ref 90$)$ with inhibitor titrations carried out in several species whose cytochrome $b$ shares one or more amino acid substitutions with the resistant species In the case of anımals, several other species were studied for such a scrutıny (man, fox, cat, sheep, turkey, toad, salamander and many fishes, results not shown)

c Relative titre of inhibition of the ubiquinol-2 (10-15 $\mu \mathrm{M})$ cytochrome $c(10 \mu \mathrm{M})$ reductase assayed with 1-3 nM of $b c_{1}$ complex as described previously $[36,39,46,90]$ Except for HQNO, which was routınely added to the assay cuvette, the inhibitors were incubated for ca 2 min with the

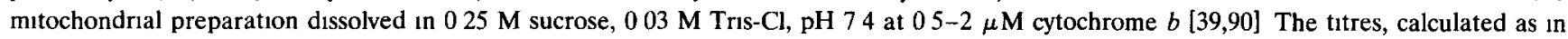
Table III and IV after normalızatıon to the content of the $b c_{1}$ complex, are the average of two or more separate titrations and are underlıned when they are significantly different from the respective average titre Although the specific titre of the inhibitors is about two-fold higher in mitochondria than in the isolated reductase, its relative ratio in different species remains constant (results not shown) Inhibitors concentration was measured as described in Ref [113]

${ }^{d}$ Funiculosin, a generous gift from Sandoz, Basel, was dissolved in slightly basic ethanol and incubated over 2 min with the preparations [90,143] The average titre of the most sensitive species, e $\mathrm{g}$, beef, was $3 \mathrm{~mol}$ per mol of $b c_{1}$ complex and has been taken as the reference (' 1 ')

${ }^{\mathrm{e}}$ HQNO from Sigma was added to the cuvette and had an average titre of $250 \mathrm{~mol}$ per mol of $b c_{1}$ complex in several anımal species and yeast wild-type strains Separate experıments were performed by incubatıng the inhibitor with the concentrated preparations or the 150 ated $b c_{1}$ complex to assess, in particular, the hypersensitivity of plants

${ }^{t}$ UHDBT was purchased from B L Trumpower and exhibited an average titre usually around $20 \mathrm{~mol}$ per mol of $b c_{1}$ complex in mammals

g The average titre of myxothıazol in mitochondria of most anımals and several wild-type yeast strains was 11 mol per mol of $b c_{1}$ complex This value is taken as the reference for calculating the relative titre

${ }^{\text {h }}$ Similar results were obtained in other plant preparations like maize and pea hypocotıles (results not shown) and crude $b c_{1}$ complex from Jerusalem artıchoke tubers [148] 
resistance towards center o inhibitors often lie in extramembrane loops and lead to high levels of resistance towards the inhıbitors $[19,36,73]$

\section{VI-D Natural resistance as a source of new structure- function relationships}

Can we exploit the natural variation of cytochrome $b$ to determine structure-function relationships? Some speculations on naturally occurring sites of altered sensitivity towards $b c_{1}$ inhibitors have already been made $[6,19,26,39,46,90,129-137]$ In order to substant1ate speculations of this kınd, a thorough investigation of the sequence to property relationship must be undertaken in several variants of a protein $[72,140]$ The numerous sequences of cytochrome $b$ that are avallable and the possibility of measuring inhibitor binding from the titrations of the cytochrome $c$ reductase activity in mitochondria $[36,39,46,90,115,133-136,138]$ have allowed us to systematically carry out this investigation Natural resistance has been found in many species (Table V), thus providing cases of altered properties that could be related to structural changes in the natural variants of cytochrome $b$

The problem is to correlate changes in the titre of one inhibitor with one (or few) specific residue substitutions that naturally occur in the sequence of cytochrome $b$ This problem is complicated by the absence of a known three-dimensional structure of the protein and by the difficulty of finding a strict one-toone relationship Two considerations, however, mitigate the problems (1) The detalled knowledge of the avalable resistant mutants can be used as a guide for locating the protein regions or deducing the type of amıno acid replacement that may cause a given inhibitor response $[9,19,26,39,73,90,129,134,137]$ (2) The natural variants of a protein are stable and fully functional $[75,140]$ In contrast, mutated proteins generally have major functional derangements $[59,72,75]$ (see $[8,18,68,76,133,135,137,141]$ for cytochrome $b$ mutants) Moreover, the 'element of surprise' [140] in the natural amıno acid variation can provide multiple substitutions for assessing the role of specific residues

Correlations between an unusual response to one $b c_{1}$ inhibitor and the sequence of the cytochrome $b$ protein are most convincing when they combine sequence analysis in related species with the information derived from mutants In the case of the natural resistance of fish to funiculosin [90], the results of a selected screening of funiculosin sensitivity in animal mitochondria suggested that the substitution of the conserved alanine 126 with the bulky methionine in the fish protein (Fig 1) is probably responsible for a substantial increase in the titre of this inhibitor relative to normally sensitive species (Table $\mathrm{V}$ and Ref 90 ) Natural resistance in the plant mitochondrial $b c_{1}$ complex [142] could also be correlated with the exchange of A126 with the bulkier $\mathrm{V}$ in the cytochrome $b$ sequence (Fig 2 and Ref 90) The buried location of position 126 within the transmembrane sector of helix $\mathrm{C}$ ( $\mathrm{F} 1 \mathrm{~g} 1)$ may account for the 'hybrid' effects of funiculosin, which effects both center $\mathbf{i}$ and center o [90,114,143146] Note that the proteins having a bulky amıno acid at position 126 also show resistance to UHDBT (Table $\mathrm{V})$, which is a center o inhibitor that shares with funiculosin the property of effecting both quinone sites $[113,114,143,144]$

An interesting property of funiculosin is its remarkable species specificity, even among mammals $[143,147]$ The volume pattern and the comparison of the sequences of sensitive and resistant species suggested previously that position 194 may also be involved in funiculosin binding [90] By inspecting the aligned sequences, we noticed that the rabbit protein shows the substitution of alanıne 194 with a bulkıer valıne residue (Fig 1) Hence, rabbit mitochondria were expected to be quite resistant to funiculosin, which would explain why rabbits are resistant to this drug in vivo [147] This is indeed the case, since the inhibitory potency of funiculosin on the ubiquinol cytochrome $c$ reductase activity is about 60 -fold lower for mitochondria isolated from rabbit than those from sensitive mammals (Table V) The cytochrome $b$ proteins of zebra and donkey also have valıne at position 194 ( $\mathrm{Fig} 1$ and Ref 32) and differ from that of pig, a species fully sensitive to funiculosin $[90,147]$, in a dozen residues withın the predicted transmembrane regions at the negative side of the membrane, where center $\mathbf{i}$ inhibitors bind $[9,26,90,136]$ With the exception of the replacement A194 $\rightarrow V$, these residue changes are seen in other mammals whose mitochondria are as sensitive to funiculosin as those of pig but over 40-tımes more sensitive than those of donkey (or its close relative horse, results not shown and Table V) We propose, therefore, that position 194 and/or its surrounding region is involved in the binding of funiculosin (see Ref 90 for further discussion of this proposal)

The screening of the responses to HQNO revealed several cases of significant alterations of its sensitivity (Table V), the most striking of which is represented by the hypersensitivity of the reductase in plant mitochondria [148] The sequence of plant cytochrome $b$ shows the unusual change $N 31 \rightarrow G$ (Fig 2) that we consider responsible for HQNO hypersensitivity for two reasons First, when N31 is mutated to a bulkier residue such as $K[26,129,132]$, resistance to HQNO is observed $[130,133]$ Since the increase in volume of the residue is the major theme in resistance mutations of center 1 inhibitors (Table III), one would expect that the considerable decrease of the volume by exchanging 
an asparagıne for a glycine would facilitate the bindıng of the quinone antagonist Secondly, the almost opposite mutation of glycine232 to aspartate induces HQNO resistance [128]

Although the cytochrome $b$ protein of trypanosomes also shows the substitution $\mathrm{N} 31 \rightarrow \mathrm{G}$, mitochondria from these protozoans are highly resistant to HQNO (Table V) This does not necessarily contradict the above correlation because several unusual substıtutions in the transmembrane helices $\mathrm{A}, \mathrm{D}$ and $\mathrm{E}$ of trypanosomal cytochrome $b$ lead to an increase in the protein volume at the negative side of the membrane (Figs 2 and 5) By combining different sequence analyses, we hypothesize that the substitutions A191 $\rightarrow$ I, $\mathrm{L} 231 \rightarrow \mathrm{F}$ and $\mathrm{G} 232 \rightarrow \mathrm{L}$ in the cytochrome $b$ of Leishmania may contribute to HQNO resistance in trypanosome mitochondria (Table $\mathrm{V}$ )

Positions 30, 31, 34 (helix A), 103 (helix B), 191, 194, 205 (helıx D), 228, 231 and 232 (helıx E) are concomıtantly altered in trypanosomes and Paramecium cytochrome $b$ with respect to most other species (Fig 2) This observation suggests that such residues are mutually related in the protein structure, in agreement with the helical packing shown in Fig 5 Moreover, the cumulative substitution of these residues probably alters the normal properties at center $\mathbf{i}$ and thus explains the strong natural resistance to both HQNO and funiculosin in the mitochondria of these protozoans (Table V) Interestingly, some of these positions are substituted in a few species that also show natural resistance to either HQNO or funiculosin (1) S34 $\rightarrow$ I occurs in $R$ capsulatus (Fig 2), which is more resistant to funiculosin than equides even though they all have the substitution A194 $\rightarrow$ V (Table V) The substitution $\mathrm{S} 34 \rightarrow \mathrm{F}$ is seen in trypanosomes and Paramecium (Fig 2) which have the strongest resistance towards funiculosin (Table V) Hence, position 34 may also be critical for funiculosin binding (2) Position 191 is usually A, and changes to the bulky $M$ in the beef and $L / I$ in the trypanosomal proteins (Figs 1 and 2) Since the cytochrome $c$ reductase of beef appears to be partially resistant to HQNO as compared to that of most antmals (Table V), position 191 may be another residue influencing sensitivity to this inhibitor (3) Position 231 is specifically changed to the bulkier $F$ in the sturgeon protein ( $F_{1 g} 1$ ) as in trypanosomes ( $\left.F_{1 g} 2\right)$ The cytochrome $c$ reductase of sturgeon mitochondria shows a significantly higher titre of HQNO than that in mitochondria of other fish and most anımals (Table V), thereby suggesting that position 231 is also involved in the binding of this inhibitor (this is further supported by the triple mutant of $K$ lactis at position 230-232 that is antımycin and HQNO resistant $[130,132]$ )

The possible location of the sensitivity positions towards inhibitors binding to cytochrome $b$ is illustrated in Fig 6A
VI-E Other information relevant for structure versus function

Table IV also lists data on functionally deficient mutants of cytochrome $b$ The photosynthetically deficient mutant G143 $\rightarrow$ D of Rhodobacter (see Ref 19 and references thereın) occurs at a position that is very critıcal for the bindıng of myxothıazol $[19,36,46,68,69$, 134] Three yeast respiratory deficient mutants which map around position 143 show only a partial decrease of the ubiquinol cytochrome $c$ reductase activity in vitro and also display a slight resistance to myxothiazol (Table IV and [149-152]) Interestingly, the mutation $\mathrm{C} 133 \rightarrow \mathrm{Y}$ [151] produces a loss in the specificity for the quinol ring (T Tron, A Ghell, J Y Coppèe, A M Colson, C Bruel, D Lemesle and M Deglı Espostı, unpublished data), since mitochondria of this mutant are more active with plastoquinol than with ubiquinol analogs These results, previous deductions based on resistance towards methoxy-acrylate inhıbitors $[19,36$, $73,134,137]$, and comparisons with the sequences of cytochrome $b_{6}$ suggest that the region comprising the end of helix $C$ and the beginning of loop cd may play a specific role in the binding of the methoxy groups which distınguish ubiquinol from plastoquinol This region also contains the only residue that is conserved in cytochrome $b$, but not $b_{6}$, at the positive side of the membrane, namely S140 ( $\mathrm{F}_{1 \mathrm{~g}} 2$ ) Moreover, the cytochrome $b$ of Ascaris, an organism possessing the rare ubiquinone analog, rhodoquinone, in which one methoxy of the ring is substituted by an amino group [127], shows the substitution of T145, conserved except in $b_{6}$ (Table II)

Although it is difficult to extrapolate common functions from sequence similarities with the reaction center subunits (see above section V-I), it is worth noting that there is a statistically relevant homology between the conserved peptide W142GATV(I) in loop cd of cytochrome $b$ and the conserved peptide H215GATV(I) in the chloroplast $D_{2}$ subunit and its homologous $M$ subunit of the bacterial reaction center (cf $\mathrm{F}_{1 \mathrm{~g}} 2$ and Refs 101, 102) In the crystal structure of the reaction center, either the histidıne (H217 in $R$ viridis [101]) or the threonine (T222 in Rhodobacter [102,104]) are hydrogen-bonded to one carbonyl of the $\mathrm{Q}_{\mathrm{A}}$ molecule It is tempting to speculate that either W142 or T145 in cytochrome $b$ might be hydrogen-bond donors to ubiquinone and methoxy-acrylate inhibitors Recent results obtained in revertants of the yeast respiratory deficient mutant $\mathrm{W} 142 \rightarrow \mathrm{R}$ suggest that this residue is involved in the binding of myxothiazol [153] (see also Table IV)

Important information has been recently obtained by the screening of secondary-site revertants of yeast respiratory deficient cytochrome $b$ mutants $[76,141$, 152-157] Some substitutions in these revertants occur 

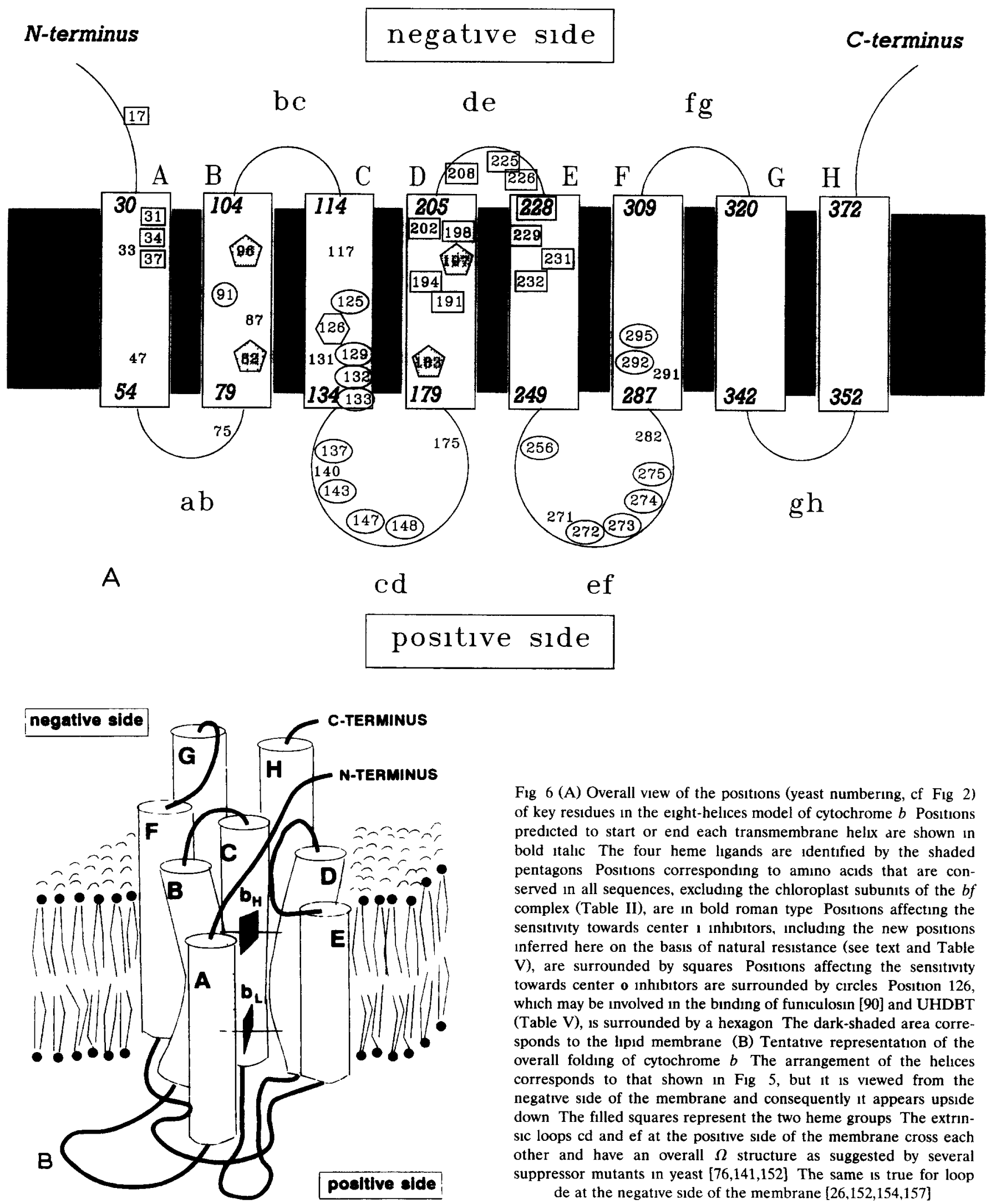

Fig 6 (A) Overall view of the positions (yeast numberıng, cf Fig 2) of key residues in the eight-helices model of cytochrome $b$ Positions predicted to start or end each transmembrane helix dre shown in bold italic The four heme ligands are identified by the shaded pentagons Positions corresponding to amino acids that are conserved in all sequences, excluding the chloroplast subunits of the $b f$ complex (Table II), are in bold roman type Positions affecting the sensitivity towards center 1 inhibitors, including the new positions inferred here on the basis of natural resistance (see text and Table V), are surrounded by squares Positions affecting the sensitivity towards center 0 inhibitors are surrounded by circles Position 126, which may be involved in the binding of funiculosin [90] and UHDBT (Table V), is surrounded by a hexagon The dark-shaded area corresponds to the lipid membrane (B) Tentative representation of the overall folding of cytochrome $b$ The arrangement of the helices corresponds to that shown in Fig 5, but it is viewed from the negative side of the membrane and consequently it appears upside down The filled squares represent the two heme groups The extrinsic loops cd and ef at the positive side of the membrane cross each other and have an overall $\Omega$ structure as suggested by several suppressor mutants in yeast $[76,141,152]$ The same is true for loop de at the negative side of the membrane $[26,152,154,157]$ 
far away in the primary sequence from the mutation leading to loss of function, thereby indicating contacts between different segments of cytochrome $b$ in the tertiary structure $[152,154]$ Though the distribution of the suppressor mutations generally overlaps the regions altering the sensitivity to center o inhibitors [76,142,152-157], insights into the foldıng of extrinsic loops have been obtained, such as the proximity of loop cd with loop ef [152]

Rare substitutions that occur naturally in the sequence of some species resemble those seen in yeast respiratory deficient mutants plus their revertants One example is given by the cytochrome $b$ of $S$ pombe [57] which shows the unusual replacement G137 $\rightarrow \mathrm{N}$ in parallel to the equally unusual replacement $\mathrm{N} 256 \rightarrow \mathrm{C}$ (F1g 2) These changes seem to compensate each other as with the phenotypic suppression of the G137 $\rightarrow E$ mutant phenotype by the secondary substitution N256 $\rightarrow \mathrm{K}$ [152] It is also interesting to observe that the sequence of magpie cytochrome $b$ [33], in which the conserved P187 is changed to $\mathrm{L}$ in helix $\mathrm{D}$, uniquely shows a proline in helix $\mathrm{C}$ ( $\mathrm{F}_{1 \mathrm{~g}} 1$ ) Given the high conservation of these helices in vertebrates, such multiple variations may compensate each other to preserve the core structure of the protein

In line with this discussion, several naturally occurring substitutions are present in protozoan cytochrome $b$ at the negative side of the membrane (Fig 5) The substitutions W30 $\rightarrow \mathrm{S}$ and G205 $\rightarrow \mathrm{W}$, which are seen exclusively in the Paramecium protein (Fig 2), might compensate volumetrically each other by analogy with the suppression of the yeast deficient mutant S206 $\rightarrow \mathrm{L}$ with the substitution W30 $\rightarrow C$ [154]

\section{Conclusions}

The data and analyses presented here contribute additional information for modeling the tertiary structure of the transmembrane helices of cytochrome $b$ In particular, the hypothetical interrelationships of helix $A, D$ and $E$ are supported by a number of inferences, including new sensitivity points towards center $i$ inhibitors (Table $\mathrm{V}$ and Fig 5 and 6A) The residues affecting the sensitivity to such inhibitors are likely to be in close contact to form a common volume of the protein $[8,19,24-28]$, by analogy with the binding site of ubiquinone $\left(Q_{B}\right)$ and its antagonists in photosynthetic systems $[24,73]$ The most conserved faces of helices A, $D$ and $E$ at the negative side of the membrane also contain the positions influencing sensitivity towards inhibitors ( $F_{1} g$ 5), thereby sustaining the packıng of these helices proposed in Fig 5

The scrutiny of previous models for the tertiary structure of cytochrome $b[8,18,25,27,28,73,152,157-$ 159] indicates that only those proposed by Crofts et al $[8,18,28]$, one discussed by Tron [157] and another advanced by Deglı Espost1 et al [158] are consistent with the most likely arrangement of helices A, D and E (cf Fig 5) Other points should be also considered for deducing the possible associations of the transmembrane helices of cytochrome $b$ First, helices $\mathrm{B}, \mathrm{C}$ and $F$ contain residues influencing sensitivity to center o inhibitors that are likely to pack close together $[18,19,24,25,28,73,152,157,158]$ Secondly, the arrangement of all helices should maximize the contacts between their conserved faces towards the interior of the protein $[8,28,103,108]$ Thirdly, helices A to D contain the conserved motif of thirteen-spaced glycines and histidines that is likely to form the heme-binding core of the cytochrome [18,36,157] Finally, loop bc is short and implies the proximity of helices $B$ and $C$ (the same is true for loop fg and gh, of Fig 2 and Ref 25)

Although each of the above points alone provides loose constraints for modeling the folding of eight helices, the combination of all of them with the optimized packing of helices $A, D$ and $E$ restricts the possible arrangements of the helices In our opinion, the arrangement of the helices that is shown in $\mathrm{Flg} 5$ and, in an overall view of the protein, in Fig 6B, seems to be most consistent with the present knowledge of cytochrome $b$ Naturally, the model is only tentative and as such is proposed to stımulate further exper1mental and theoretical analysis

As a concluding comment, it is hoped that this review will provide useful information also to scientists who study cytochrome $b$ in fields traditionally distinct from bioenergetics, such as evolutionary biology

\section{Acknowledgements}

Research in Bologna was sponsored by grants from MURST to M Deglı Espostı and from CNR, progetto finalızzato Bıtecnologie e Biostrumentazıone, to Prof G Lenaz, who is warmly thanked for support and encouragement We thank Dr L Bargelloni for his contribution to sequencing and Prof $G$ Marın for DNA samples of birds Research in Padua was also supported by Progetto Nazionale Ricerche in Antartıde Research of A Meyer at Stony Brook was sponsored by grants from U S National Science Foundation BSR-9107838 and BSR-9119867

Exchange of information is gratefully acknowledged with the following colleagues $\mathrm{Dr} P$ Arctander (Copenhagen), Dr B Block (Chicago), Prof P Cantatore (Barı), Dr A Cockburn (Gainesville), Prof R H Crozier (Bandoora - Australıa), Dr J Feagin (Seattle), Prof M W Gray (Halifax - Canada), Dr A Graybeal (Berkeley), Prof R Gennis (Urbana), Dr S B Hedges (Unıversity Park - Pennsylvanıa), Dr A P Martın (Mıamı), Prof B A Melandrı (Bologna), Dr P Rich (Bodmın), Dr A Richman and Dr T Price (San Diego), Dr N Sone (Fukuoka), Prof A Trebst (Bochum), Dr A Wakefield (Oxford) 


\section{References}

1 Von Jagow, G and Sebald, W (1980) Annu Rev Biochem 49, 281-314

2 Slater, E C (1981) in Chemısmotic Proton Circults in Biolog1cal Membranes (Skulachev, V P and Hinkle, P, eds), pp 69-104, Elsevier, Amsterdam

3 Hauska, G, Hurt, E, Gabellını N and Lockau W (1983) Biochım Biophys Acta 726. 97-133

4 Mahler, HR and Perlman PS (1985) in The Enzymes of Biological Membranes (Martonosi, A N, ed), Vol 4, pp 195234 Plenum Press, New York

5 De Vries, S and Marres CA (1987) Biochım Biophys Actd $895 \quad 205-239$

6 Howell. N (1989) J Mol Evol 29, 157-169

7 Dutton PL (1986) in Encyclopedia of Plant Physiology (Staehelın A and Arntzen, CJ, eds). Vol 19 pp 197-237, Springer, Berlin

8 Crofts, A, Hacker, B, Barquera B Yun, C H and Gennis R (1992) Bıochım Biophys Acta 1101, 162-165

9 Trumpower, B L (1990) Microbiol Rev 54 101-129

10 Cramer, W A Black, M T Widger, W R and Girvin, ME (1987) in The Light Reactions (Barber J, ed) pp 447-493, Elsevier, Amsterdam

11 Hauskd, G, Nitschke, W and Herrmann R G (1988) J Bıenerg Biomembr 20, 211-228

12 Widger, W R and Cramer, W A (1991) in Cell Culture and Somatic Cell Genetics of Plants, Vol 7B, pp 149-176, Acddemic Press, New York

13 Mitchell P (1975) FEBS Lett 56, 1-6

14 Mitchell P (1990) in Highlights in Ubıquinone Research (Lenaz, $G$ et al, eds ), pp 77-82, Taylor \& Francis, London

15 Rich, P R (1986) J Bioenerg Biomembr 18, 145-156

16 Wikstrom, M and Saraste, M (1984) in Bioenergetıcs (Ernster, $\mathrm{L}$ ed ), pp 49-94, Elsevier, Amsterdam

17 Mansfield R W and Wiggins, T E (1990) Biochım Biophys Acta $1015,109-115$

18 Yun C H, Wang, Z G Crofts A R and Gennıs, P B (1992) J B1ol Chem 267,5901-5909

19 Daldal, F, Tokıto, M K Davidson, E and Faham M (1989) EMBO J 3951-3961

20 Chance, B, Wilson, D F, Dutton, P L and Erecinskd M (1970) Proc Natl Acad Sc1 USA 66, 1175-1182

21 Deglı Espostı, M, Palmer, G and Lenaz, G (1989) Eur J B1ochem 182, 27-36

22 Saraste, M (1984) FEBS Lett 166, 367-372

23 Widger, W R. Cramer, W A Herrmann, R G and Trebst, A (1984) Proc Natl Acad Scı USA 81, 674-678

24 Crofts A Robinson, H, Andrews, K, Van Doren, S and Berry E (1987) in Cytochrome Systems Molecular Biology and Bioenergetics (Papa, S, Chance, B and Ernster, L eds), pp 617-624, Plenum Press New York

25 Brasseur, R (1988) J Biol Chem 263, 12571-12575

26 Di Rago, J P and Colson, A M (1988) J Biol Chem 263 $12564-12570$

27 Deglı Espostı, M and Crımı, M (1990) in Highlıghts in Ubıquinone Research (Lenaz, $G$ et al eds), pp 166-169, Taylor \& Francis, London

28 Crofts, A, Wang Z, Chen, Y Mahalıngham, S, Yun, C H and Gennis. R B (1990) in Highlights in Ubıquinone Research (Lenaz, G et al eds), pp 98-103, Taylor \& Francis, London

29 Kocher, T D Thomas, W K, Meyer, A. Edwards, S V , Paabo S, Villablanca, F X and Wilson, A C (1989) Proc Natl Acad Scı USA 86, 6196-6200

30 Meyer A, Kocher, T D, Babasibwakı, P and Wilson, AC (1990) Nature 347, 550-553

31 Meyer A and Wilson A C (1990) J Mol Evol 31, 359-365
32 Irwin, D M, Kocher, T D and Wilson, A C (1991) J Mol Evol 32, $128-144$

33 Edwards, SV Arctander, P and Wilson A C (1991) Proc Roy Soc London 243 99-107

34 Bashford, D, Chothia, C and Lesk A M (1987) J Mol Biol $196,199-216$

35 Nelson, DR and Strobel HW (1988) J Biol Chem 263 6038-6050

36 Tron, T, Crımı M Colson, A M and Deglı Espostı, M (1991) Eur J Brochem 199, 753-760

37 Nobrega, F G and Tzagolotf, A (1980) J Biol Chem 255 9828-9837

38 Higgings, D G and Sharp, P M (1988) Gene 73 237-244

39 Ghellı, A Crımı, M, Orsını, S, Gradonı, L, Zannottı, M Lenaz G and Degh Espostı, M (1992) Comp Brochem Physol 103B, 329-338

40 Thornton, J M, Flores, T P, Jones D T and Swindells, M B (1991) Nature 354 105-106

41 Tian G L Michel, F Macadre C, Slonımskı P P and Lazowska, J (1991) J Mol Bıl 218, 747-760

42 Von Jagow, G, Engel, W D Schagger, $H$ Machleıdt, $W$ and Machleidt, I (1981) in Vectorial Reactions in Electron and Ion Transport in Mitochondrid and Bacteria (Palmierı, F et al eds), pp 149-161, Elsevier Amsterdam

43 Majewsk1, C and Trebst, A (1990) Mol Gen Genet 224 373-382

44 Yun, C H Becı, R, Crofts A R Kaplan, S and Gennis, R B (1990) Eur J Biochem 194 399-411

45 Jacobs, H T Ellot, D J Math, V B and Farquharson, A (1988) J Mol Biol 202, 185-217

46 Deglı Espostı, M, Ghellı, A, Butler, G, Robertı M Mustıch A and Cantatore, P (1990) FEBS Lett 263, 245-247

47 Vaidya, A B, Akella, R and Suplick, K (1990) Mol Biochem Parasitol 39, 295-296

48 Benne, R (1989) Biochım Biophys Acta 1007, 131-139

49 Feagin, J E, Shaw, J M , Simpson L and Stuart, K (1987) Proc Natl Acad Scı USA 85, 539-543

50 Mahendran R Spottswood M R and Miller D L (1991) $\mathrm{Nd}_{\mathrm{d}}$ ture $349,434-438$

51 Gualberto, J M Lamattına L, Bonnard, G Weıl J H and Grienenberger, J M (1989) Nature 341, 660-662

52 Schuster W Hiesel, R, Wissinger B and Brennicke A (1990) Mol Cell Biol 10, 2428-2431

53 Schuster W, Ternes, R, Hiesel R, Wissinger, B and Brennıcke A (1991) Curr Genet 20, 397-404

54 Okımoto, R. Macfarlane, J L Clary, D O and Wolstenholme, D R (1992) Genetıcs 130, 474-498

55 Roe, B A, Ma, D P Wilson, R K and Wong, J F (1985) J B1ol Chem 260, 9759-9774

56 Pritchard, A E, Sable, C L, Venutı, S E and Cummings, D J (1990) Nucleic Acid Res 18, 163-171

57 Lang, B F, Ahne, F and Bonen, L (1985) J Mol Bol 184 353-366

58 Dickerson, R E (1972) Scientific American 226, 58-72

59 Hampsey, D M Das G and Sherman F (1986) J Biol Chem $261,3259-3271$

60 Hedges B S, Bezy, RL and Maxson L R (1991) Mol Biol Evol 8, 767-780

61 Hedges S B, Bogart J P and Maxson, L R (1992) Nature 356 $708-710$

62 Edwards, S V and Wilson, A C (1990) Genetıcs 126, 695-711 63 Desjardıns P and Mora1s R (1990) J Mol Biol 212, 599-634

64 Normark B B, McCune, A R and Harrison RG (1991) Mol Biol Evol 8, 819-834

65 Yun, C H Crofts, A R and Gennıs, R B (1991) Biochemıstry $30,6747-6754$ 
66 Wuttke, D S, Bjerrum, M J, Winkler, J R and Gray, H B (1992) Science 256, 1007-1009

67 Moser, C C, Keske, J M , Warncke, K, Farıd, R S and Dutton, P L (1992) Nature 355, 796-902

68 Atta-Asafo-Adjel, E and Daldal, F (1991) Proc Natl Acad Scı USA 88, 492-496

69 Tokıto, M K, Gray, K A, Davıdson, E, Park, S,Y and Daldal, F (1992) 7th EBEC Short Reports 19

70 Lubben, M, Kolmerer, B and Saraste, M (1992) EMBO J 11, 805-812

71 Deglı Espostı, M (1989) Bıochım Bıophys Acta 977, 249-265

72 Ackers, G K and Smith, F R (1985) Annu Rev Biochem 54, 597-629

73 Robertson D E, Daldal, F and Dutton, L (1990) Bıchemistry $29,11249-11260$

74 Schejter, A, Luntz, T L, Koshy, T I and Margoliash, E (1992) Bıchemistry 31,8336-8343

75 Chothı, C and Finkelsteın, A V (1990) Annu Rev Biochem $59,1007-1039$

76 D1 Rago, J P, Netter, P and Slonımskı, P P (1990) J Bıol Chem 265, 3332-3339

77 Doolittle, W F and Sapienza, C (1980) Nature 284, 601-603

78 Dawkıns, R (1982) The Extended Phenotype, Oxford Unıversity Press, Oxford

79 Smıth, M F, Thomas, W K and Patton, J L (1992) Mol Biol Evol 9, 204-215

80 De Vries S, Albracht, S P J, Marres, C A M and Slater, E C (1983) Biochım Biophys Acta 723, 91-103

81 Ding, H, Robertson, D E, Daldal, F and Dutton, P L (1992) Biochemistry 31, 3144-3158

82 Sone, $\mathrm{N}$ et al (1991) Abstract $64^{\text {th }}$ Meetıng Japanese Bıchemıcal Society, Tokyo

83 Woese, C R (1987) Microbiol Rev 51, 221-271

84 Douglas, S E, Murphy, C A, Spencer, D F and Gray, M W (1991) Nature 350, 148-151

85 Thomas, R H, Shaffner, W, Wilson, A C and Paabo, S (1989) Nature $340,465-467$

86 Smith, MF and Patton, J L (1991) Mol Biol Evol 85-103

87 Shields, G F and Kocher, T D (1991) Evolutıon 45, 218-221

88 Strumbauer, C and Meyer, A (1992) Nature 358, 578-581

89 Meyer, A (1992) in Biochemistry and Molecular Biology of Fishes (Hochachka, PW and Mommsen, T P, eds), Vol 2, Elsevier, Amsterdam, in the press

90 Deglı Espostı, M, Ghellı, A, Crımı, M, Baracca, A, Solaını, G, Tron, T and Meyer, A (1992) Arch Biochem Biophys 295 , 198-204

91 Richman, A D and Price T (1992) Nature 355, 817-821

92 Kyte, J and Doolittle, R F (1982) J Mol Biol 157, 105-132

93 Rao, M J K and Argos, P (1986) Bıochım Biophys Acta 869, $197-214$

94 Deglı Espostı, M, Ghellı, A , Luchettı, R , Crımı, M and Lenaz, G (1989) Ital J Biochem 38, 1-22

95 Deglı Espostı, M, Crımı, M and Venturolı, G (1990) Eur J Biochem 190, 207-219

96 Gabellinı N and Sebald, W (1986) Eur J Biochem 154, $569-579$

97 Argos, P and Rao, M J K (1985) Bıochım Bıophys Acta $827,283-297$

98 Yun, C H, Vandoren, S R, Crofts, A R and Gennis, R B (1991) J Biol Chem 266, 10967-10973

99 Cramer, W and Trebst, A (1991) Trends Biochem Sc1 16, 207

100 Fasman, G,D, and Gilbert, W A (1990) Trends Blochem Scl $15,89-92$

101 Deisenhofer, J and Michel, H (1989) EMBO J 8, 2149-2170

102 Komyra, H, Yeates, T O. Rees, D C, Allen, J P and Feher, G (1988) Proc Natl Acad Scı USA 85, 9012-9016
103 Rees, D C, Komyı, H, Yeates T O, Allen, J P and Feher, G (1989) Annu Rev Biochem 58, 607-633

104 El-Kabbanı, O, Chang, C H, Tiede, D, Norris, J and Schiffer, M (1991) Blochemistry, 30, 5361-5369

105 Ohnıshı, T, Schagger, H, Meınhardt, S W , LoBrutto, R, Lınk, $\mathrm{T} A$ and Von Jagow, $\mathrm{G}$ (1989) J Biol Chem 264, 735-744

106 Robertson, DE and Dutton, P L (1988) Bıochım Biophys Acta 935, 273-299

107 Eisenberg, D (1984) Annu Rev Bıochem 53, 595-623

108 Rees, D C , Deantonı L and Eisenberg, D (1989) Science 245, $510-513$

109 Crımı, M and Deglı Espostı, M (1991) Trends Bıochem Scı 16, 119

110 Yue, W H, Zou, Y P Yu L and Yu, C A (1991) Bıchemıstry $30,2303-2304$

111 Kubota, T, Kawamoto, M, Fukuyama, K, Shınzawa-Itoh, K Yoshıkawa, S and Matsubara, H (1991) J Mol Bıl 221 379-382

111a Berry, E, Huang, L S, Earnest, T N and Jap, B K (1992) J Mol Bıol 224, 1161-1164

112 Von Jagow, G and Engel, W D (1981) FEBS Lett 136, 19-24

113 Von Jagow, G and Lınk, T A (1986) Methods Enzymol 126 253-271

114 Tsal, A L, Kauten, R and Palmer, G (1985) Bıchım Bıophys Acta $806,418-426$

115 Brandt, U, Schagger, $H$ and Von Jagow, G (1988) Eur J Biochem 173, 499-506

116 Tietjen, K G, Kluth, J F, Andree, R, Haug, $M$ Lindig, M, Muller, K H, Wroblowsky H J and Trebst, A (1991) Pestıc Sc1 31, 65-72

117 Bowyer, J R, Camıllerı, P and Vermaas, W F J (1991) in Herbicides (Baker, N R and Percival, MP, eds), pp 27-85 Elsevier, Amsterdam

118 Oettmeier, W (1992) in The Photosystems Structure, Function and Molecular Biology (Barber, J, ed ), pp 349-408, Elsevier, Amsterdam

119 Sinnıng, I, Michel, H , Mathis, P and Rutherford, A W (1989) Biochemistry $28,5544-5553$

120 Sinning, I (1992) Trends Biochem Scl 17 150-154

121 Oettmeier W, Godde, D, Kunze, B and Hofle, G (1985) Biochım B1ophys Acta 807, 216-219

122 Barton, J R, MacPeek, W A and Cohen, W S (1983) J Bioenerg Biomembr 15, 93-104

123 Glanglacomo, K M, Robertson, D E, Gunner, M R and Dutton, D L (1987) in Progress in Photosynthesis Research (B1ggıns, J, ed ), Vol 2, P 409-412, Martınus Nıhoff, Dordrecht

124 Palmer, G (1990) in Highlights in Ubıquinone Research (Lenaz, G et al, eds ), pp 83-91 Taylor \& Francıs, London

125 Salerno, J C, Osgood, M, Lyu Y, Taylor H and Scholes, C R (1990) Biochemistry 29, 6987-6993

126 Brandt, V, Haase, U, Schagger, H and Von Jagow C (1991) J Biol Chem 266, 19958-19964

127 Takamıya, S, Furushıma, R and Oya, H (1984) Mol Bıochem Parasitol 13,121-134

128 Howell, N, Appel, J, Cook, J P, Howell, B and Hauswirth, W W (1987) J Biol Chem 262, 2411-2414

129 Di Rago, J P. Perea, J and Colson, A M (1986) FEBS Lett 208, 208-210

130 Brunner, L A, Mendoza, R V and Tuena de Cobos, A (1987) Cur Genet 11, 475-482

131 Weber, S and Wolf, K (1988) FEBS Lett 237, 31-34

132 Coria R Garcia, M and Brunner, A (1989) Molec Microbıl 3, 1599-1604

133 Briquet, $M$ and Goffeau, A (1981) Eur J Biochem 117 333-339

134 Howell, N and Gilbert, K (1988) J Mol Biol 203, 607-618 
135 Howell, N (1990) Biochemistry 29, 8970-8977

136 Di Rago, J P Perea, J and Colson, A M (1990) FEBS Lett 263, 93-98

137 D1 Rago, J P, Coppée, J P, and Colson, A M (1989) J Biol Chem 264, 14543-14548

138 Ge1er, B M , Schagger, H, Brandt, U, Colson, A M and VonJagow, G (1992) Eur J Blochem 208, 375-380

139 Bennoun P, Delosme, $M$ and Kuck, U (1991) Genetıcs 127 335-343

140 Laskowsk1, M Jr, Kato, I, Ardelt, W, Cook, J Denton, A, Empie M W, Kohr, W J, Park, S J, Parks, K Schatzley, B L Schoenberger, OL, Tashıro, $M$, Vichot, $G$, Whatley $\mathrm{HE}$, Wieczorek A and Wieczorek, M (1987) Bıochemistry 26, 202221

141 Tron, T, Infossı, P, Coppée, J P and Colson, A M (1991) FEBS Lett 278, 26-30

142 Berry, E A Huang, L and De Rose, V (1991) J Biol Chem 266, 9064-9077

143 Rieske, J S (1980) Pharm Ther 11, 415-450

144 Deglı Espostı, M. Tsaı, A M, Pálmer, G and Lenaz G (1986) Eur J Blochem 160 547-555

145 Kamensky, Y, Konstantınov A A, Kunz, W S and Surkov, S (1985) FEBS Lett 181, 95-99

146 Rich, P R Jeal, A E, Madgwick, S A and Moody J (1990) Biochim Biophys Acta 1018, 29-40

147 Ando, K, Matsuura, I, Nawata, Y Endo, H, Sasakı, H Okytomı, T, Saehı, T and Tamura, C (1978) J Antıbıotıcs A 31 $533-538$

148 Deglı Espostı, M, Flamını, E and Zannonı, D (1985) Plant Physiol 77, 758-764

149 Tron $T$ and Lemesle-Meunier, D (1990) Curr Genet 18 413-419

150 Lemesle-Meunier, D (1989) Bıochımı 71, 1145-1155

151 Brivet-Chevillotte, $P$ and Di Rago, J P (1989) FEBS Lett 255 , 5-9

152 Di Rago, J P, Netter, P and Slonımskı, P P (1990) J Biol Chem 265 15750-15757

153 Bruel, C, Di Rago, J P Netter, P, Slonımskı, P P and Lemesle-Meunier, D (1992) Seventh EBEC Short Reports, pp 24

154 Coppée, J Y and Colson, A M (1990) Suxth EBEC Report, pp 7

155 Colson, A M, Edderkaouı, B and Coppée, J Y (1992) Bıchım Biophys Acta 1101, 157-161

156 Brasseur G, Raymond, S and Brivet-Chevillotte P (1992) Seventh EBEC Reports, p 23

157 Tron, T (1991) Ph D Thesis, University of Marselle

158 Deglı Espostı, M, Ghellı, A and Crımı, M (1991) Ital Bıochem Soc Trans, Vol 2 p 112

159 Link T A Schagger, $H$ and Von Jagow, $G$ (1986) FEBS Lett 204, 9-15

160 Suplıck, K, Morrisey, J and Vaıdya, A B (1990) Mol Cel Bıol $10,6381-6388$

161 Megson, A, Inman, G J, Hunt, P D, Baylıs, H A and Hall, R (1991) Molec Biochem Parasitol 48, 113-116

162 Ossorio, P N, Sibley, L D and Boothroyd, J C (1991) J Mol Biol $222525-536$

163 Feagın JE (1992) Mol Biochem Parasitol 52, 145-148

164 Anderson, S Bankıer, A T, Barrel, B G, De Bruın, M H L, Coulson, A R, Drovin, J, Eperon, I C, Nierlıch, D P, Roe, B A, Sanger, F, Schreter, P H, Smith, A J H and Young, I G (1981) Nature 290, 457-465

165 Anderson, S De Bruın, M H L, Coulson, A R, Eperon, I C , Sanger, $F$ and Young, I G (1982) J Mol Biol 156, 683-717

166 Bibb, M J Van Etten, R A, Wright, C T, Walberg, M W and Clayton, D A (1981) Cell 26, 167-180

167 Koıke, K, Kobayashı, M, Yagınuma, K, Taıra M Yoshıda, E and Ima1, $M$ (1982) Gene 20, 177-185
168 Gadaleta, G , Pepe, G, De Candia G, Quagliariello, E, Sbisd, E and Saccone, C (1989) J Mol Evol 28, 497-516

169 Mignotte, F Gueride M, Champagne, A M and Mounolou, J C (1990) Eur J Biochem 194, 561-571

170 Arnason, U, Gulberg A and Widegreen, B (1991) J Mol Evol $33 \quad 556-568$

171 Arnason, U and Johnsson, E (1992) J Mol Evol 34, 493-505

172 Southern, S O, Southern, P J and Dizon A E (1989) J Mol Evol 28 32-42

173 Wavne, R K and Jenks, S M (1991) Nature 351, 565-568

174 Hiendleder, S, Hecht, W, Dzapo, V and Wassmuth, R (1992) Anımal Gen 23, 151-160

175 Smith EFG, Arctander, P Fjeldsd, J and Amır OG (1991) Ib1s $133,227-235$

176 Lanyon, S M (1992) Science 255, 77-79

177 Taberlet P Meyer, A and Bouvet, J (1992) Mol Ecology 1 27-36

178 Carr, S and Marshall, H D (1991) Can J Fish Aquat Sci 48 $48-52$

179 Brown, J R, Gılbert, T L, Kowbel, D J , O'Hard, P J , Buroker, NE, Beckenbach, A T and Smith, H J (1989) Nucleic Acids Res 17,4389

180 Martın, A P, Naylor, G J P and Palumbı, S R (1992) Nature $357,153-155$

181 Patarnello, T, Bargellon, L, Caldara, F and Colombo, L (1993) Molec Mar Biol Biotechnol, in press

182 Patarnello, T, Bargellont, L, Caldara, F and Colombo, L (1993) submitted

183 McVeigh, H P and Davidson W S (1981) J Fish Biol 39, 277-282

184 McVeigh, H P, Barlett S E and Davidson W S (1991) Aquaculture $95,225-233$

185 Barlett. S E and Davidson, W S (1991) Can J Aquat Scı 48 , 309-317

186 Finnerty, J R and Block, B A (1992) Mol Mar Biol Biotechnol 1 206-214

187 Grachev M A Slobodyanyuk, S J , Kholodılov N G, Fyodorov S P, Belıkov, S J , Arbakov, O J, Sıdeleva, V G, Zubın, A A and Kharchenko, V V (1992) J Mol Evol 34, 85-90

188 Cantatore, P, Robertı, M, Rainaldı, G, Gadaleta $\mathrm{MN}$ and Saccone, C (1989) J Biol Chem 264, 10965-10975

189 Smith, M J Banfield, D K, Doteval, K, Gorskı, S and Kowbel D J (1989) Gene 76, 181-185

190 Asakawa S, Kumazawa Y, Arakı, T, Hımeno, H, Mıra K I and Watanabe, $\mathrm{K}$ (1991) J Mol Evol 32, 511-520

191 Clary D O Wahletthner, J A and Wolstenholme D R (1984) Nucleic Acids Res 12, 3747-3762

192 Cockburn, A F, Mitchell, S E, and Seawright, J A (1990) Arch Insect Biochem Physiol 14, 31-36

193 Stanton, D J , Crease, T J and Herbert, P D N (1991) J Mol Evol 33, 152-155

194 Crozier, R H and Crozıer, YC (1992) Mol Biol Evol 9 , $474-482$

195 Wolstenholme, D R, Okımoto, R, MacFarlane, J L, Chamberlin, H M, Garey, J R and Okada, N A (1989) in Structure, Function and Biogenesis of Energy Transfer Systems (Quagliariello E, Papa, S, Palmierı, F and Saccone, C, eds ), pp 103-116, Elsevier, Amsterdam

196 Brown, W M, Boore, J L and Hoffman, R (1992) Genetics 131, $397-412$

197 Dejardıns, $P$ and Moraıs, R (1991) J Mol Evol 32, 153-161

198 Brunner, A and Corıa, R (1989) Yeast 5, 209-218

199 Waring, R B, Davies, R W , Lee, S, Grisi, E Mc Phail, U, Berks, M Scazzocchio, C (1981) Cell 27, 4-11

200 Collıns, R A, Reynolds, C A and Olıve J (1988) Nucleıc Acıds Res 16, 1125-1134

201 Cummings, D J, Michel, F and McNally K L (1989) Curr Genet 16, 407-418 
202 Pixley, F J, Wakefield, A E, Banerıı, S and Hopkın, J M (1991) Mol Microbiol 5, 1347-1351

203 De Ia Cruz, V F, Neckelmann, N and Simpson, L (1984) J Bıol Chem 259, 15136-15147

204 Sloof, P, Van der Burg, J, Voogd, A and Benne, R (1987) Nucleic Acids Res 15, 51-65

205 Aldritt, M, Joseph, A J and Wirth, D F (1989) Molec Cell Biol 9, 3614-3620

206 Michaelıs, G, Vahrenholz, C and Pratje, E (1990) Molec Gen Genet 223, 211-216

207 Lee, R W, Dumas C, Lemieux, C and Turmel, D (1991) Mol Gen Genet 231,53-58

208 Waddle, J A, Schuster, A M, Lee, K W and Meınts, R H (1990) Plant Mol Biol 14, 187-195

209 Boer, P, McIntosh, J , Gray, M W and Bonen, L (1985) Nucleic Acids Res 13, 2281-2292

210 Dawson, A J , Jones, V P and Leaver, C J (1984) EMBO J 3, 2107-2113

211 Kaleıkav, E K, Andre', C P Doshı, B and Walbot, V (1990) Nucleic Acids Res 18, 372

212 Zanlungo, S, Litvak, S and Jordana, X (1991) Plant Mol Biol $173,527-530$

213 Wahleithner, J A and Wolstenholme, D R (1988) Nuclesc Acids Res 16, 6897-6913

214 Oda, K, Yamato, K, Ohta, E, Nakamura, Y, Takemura, M, Nozato, N, Akashı, K, Kanegae, T, Ogura, Y, Kohchı, T and Ohyama, K (1992) J Mol Bıol 223, 1-7

215 Verbıs, J, Lang, F, Gabellını, N and Oesterhelt, D (1989) Mol Gen Genet 219, 445-452

216 Thony-Meyer, L, Stax, D and Hennecke, H (1989) Cell 57, 683-697

217 Davidson, E and Daldal, F (1987) J Mol Biol 195, 13-24

218 Kurowski, B and Ludwig, B (1987) J Biol Chem 262, 1380513811

219 Heinemeyer, W, Alt, J and Herrmann, R G (1984) Curr Genet 8, 543-549

220 Shınozakı, K, Ohme, M , Tanaka, M , Wakasugı, T, Hayashıda, $\mathrm{N}$, Matsubayashı, T, Zatta, N, Chunwongse, J, Obokata, J, Yamagıchı-Shınozakı, K, Ohto, C, Torazawa, K, Meng, B JY, Sugita, M, Deno, H, Kamogashıra, T, Yamada, K, Kusuda, J, Taıkawa, F, Kato, A, Tohdoh, N, Shımada, H and Sugıura, S (1986) EMBO J 5, 2043-2049

221 Rock, C D, Barkan, A and Taylor, W L (1987) Curr Genet $12,69-77$

222 Lehmbeck, J, Stummann, B M and Hennıngsen, K W (1989) Physiol Plant 76, 57-64

223 Hird, S M , Wilson, R J, Dyer, T A and Gray, J C (1991) Plant Mol Biol 16, 745-747

224 Reverdatto, S V , Andreeva, A V , Buryakova, A A, Chakhmakhcheva, OG and Efımov, VA (1989) Nucleıc Acıds Res 17, 2859-2860

225 Cote, J C, Wu, N H and Wu, R (1988) Plant Mol Biol 11, 873-874

226 Fukuzawa, H, Yoshıda, T, Kohchi, T Okumura, T, Sawano, Y and Ohyama, K (1987) FEBS Lett 220, 61-66
227 Reımann, A and Kuck, U (1989) Plant Mol Biol 13, 255-256

228 Buschlen, S, Choquet, Y, Kuras, R and Wollman, F A (1991) FEBS Lett 284, 257-262

229 Kallas, T, Spıller, S and Malkın, R (1988) J Bıol Chem 263, $14334-14342$

230 Phillıps, A C and Gray, J C (1984) Mol Gen Genet 194, 477-484

231 Kuck, U (1989) Mol Gen Genet 218, 257-265

232 Turmel, M, Boulanger, J and Bergeron, A (1989) Nucleic Acids Res 17, 3593

233 Osiewacz, H (1992) Arch Microbıol 157, 336-342

234 Colson, A M and Slonımskı, P P (1979) Mol Gen Genet 167, 287-298

235 Pratje, E and Michaelıs, G (1977) Mol Gen Genet 152, $167-174$

236 Michaelıs, G (1976) Mol Gen Genet 146, 183-186

237 Subık, J, Kovacova, V and Takacsova, G (1977) Eur J Biochem 73, 275-286

238 Thierbach, G and Michaelıs, G (1982) Mol Gen Genet 186, 501-506

239 Bennoun, P, Delosme, M, Godehardt, I and Kuck, U (1992) Mol Gen Genet 234, 147-154

240 Fernandez-Velasco, J G, Cocchı, S, Nerı, M, Hauska, G and Melandrı, B A (1991) J Bioenerg Biomembr 23, 365-379

241 Subık, J and Takacsova, G (1978) Mol Gen Genet 161, 99-108

242 Subık, J, Brıquet, M and Goffeau, A (1981) Eur J Biochem $119,613-618$

243 Gunner, S, Robertson, D E, Yu, L, Qu, Z, Yu, C A and Knaff, D B (1991) Biochım Biophys Acta 1058, 269-279

244 Johns, D R and Neufeld, M J (1991) Biochem Biophys Res Commun 181, 1358-1364

245 Brown, M D, Vojavec, A S, Lott, M T, Torrionı, A, Yang, C C and Wallace, D C (1992) Genetıcs 130, 163-173

246 Bırt, T P, Friesen, V L, Green, J M , Montevecchı, W A and Davidson, W S (1992) Hereditas 117, 67-72

247 Sankoff, D, Leduc, G, Antome, N, Paquin, B, Lang, B F and Cedergren, R (1992) Proc Natl Acad Scı USA 89, 6575-6579

248 Garesse, R (1988) Genetics 118, 649-663

249 Tzeng, C S, Hul, C F, Shen, S C and Huang, P C (1992) Nucleıc Acıds Res 20, 4853-4858

250 Haberhausen, G, Valentın, K and Zetshe, K (1992) Mol Gen Genet 232, 154-161

251 Hıratsuka, J , Shımada, H, Whıttıer, R, Ishıbashı, T, Sakamoto, M , Monı, M , Kondo, C, Honı, Y, Sun, C R , Meng, B Y, Li, Y Q, Kanno, A, Nıshıkawa, Y, Haraı, A, Shınozakı, K and Sugiura, M (1989) Mol Gen Genet 217, 185-194

252 Krajewskı, C, Driskell, A C, Baverstock, P R and Braun, M J (1992) Proc R Soc London B 250, 19-27

253 Arnason, U, Splliaert, R, Palsdottır, A and Arnason, A (1991) Hereditas 115, 183-189

254 Jermın, L S and Crozıer, R H (1993) J Mol Evol, submitted

255 Kornegay, J R, Kocher, T D, Willams, L A and Wilson, A C (1993) J Mol Evol, in press 